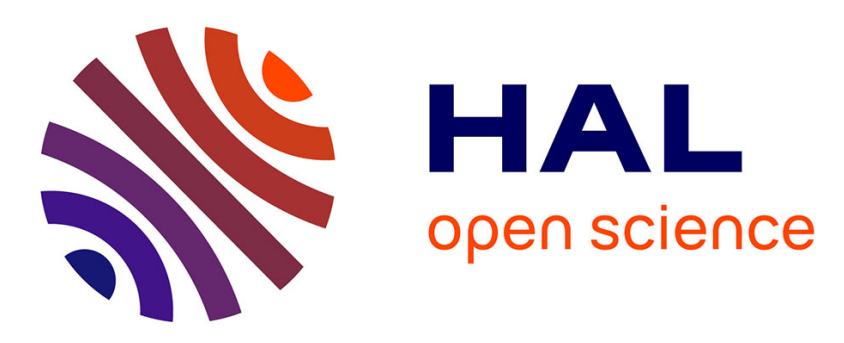

\title{
Modeling of CO2 Leakage up Through an Abandoned Well from Deep Saline Aquifer to Shallow Fresh Groundwaters
}

Pauline Humez, Pascal Audigane, Julie Lions, Christophe Chiaberge, Gaël Bellenfant

\section{To cite this version:}

Pauline Humez, Pascal Audigane, Julie Lions, Christophe Chiaberge, Gaël Bellenfant. Modeling of CO2 Leakage up Through an Abandoned Well from Deep Saline Aquifer to Shallow Fresh Groundwaters. Transport in Porous Media, 2011, 90 (1), pp.153-181. 10.1007/s11242-011-9801-2 . hal00665359

\section{HAL Id: hal-00665359 \\ https: / hal-brgm.archives-ouvertes.fr/hal-00665359}

Submitted on 1 Feb 2012

HAL is a multi-disciplinary open access archive for the deposit and dissemination of scientific research documents, whether they are published or not. The documents may come from teaching and research institutions in France or abroad, or from public or private research centers.
L'archive ouverte pluridisciplinaire HAL, est destinée au dépôt et à la diffusion de documents scientifiques de niveau recherche, publiés ou non, émanant des établissements d'enseignement et de recherche français ou étrangers, des laboratoires publics ou privés. 


\section{MODELING OF CO2 LEAKAGE UP THROUGH AN ABANDONED WELL FROM DEEP SALINE AQUIFER TO SHALLOW FRESH GROUNDWATERS}

Pauline Humez, Pascal Audigane, Julie Lions, Christophe Chiaberge and Gaël Bellenfant

BRGM - Water Division, French Geological Survey, 3 Av. Claude Guillemin, 45060 Orléans Cedex 2, France

e-mail: p.humez@brgm.fr

URL: www.brgm.fr

\section{Abstract}

This article presents a numerical modeling application using the code TOUGHREACT of a leakage scenario occurring during a $\mathrm{CO}_{2}$ geological storage performed in the Jurassic Dogger formation in the Paris Basin. This geological formation has been intensively used for geothermal purposes and is now under consideration as a site for the French national program of reducing greenhouse gas emissions and $\mathrm{CO}_{2}$ geological storage. Albian sandstone, situated above the Dogger limestone is a major strategic potable water aquifer; the impacts of leaking $\mathrm{CO}_{2}$ due to potential integrity failure have therefore to be investigated. The present case study illustrates both the capacity and the limitations of numerical tools to address such a critical issue.

The physical and chemical processes simulated in this study have been restricted to:

(i) supercritical $\mathrm{CO}_{2}$ injection and storage within the Dogger reservoir aquifer,

(ii) $\mathrm{CO}_{2}$ upwards migration through the leakage zone represented as a $1 \mathrm{D}$ vertical porous medium to simulate the cement-rock formation interface in the abandoned well

(iii) impacts on the Albian aquifer water quality in terms of chemical composition and the mineral phases representative of the porous rock by estimating fluid-rock interactions in both aquifers. 
Because of CPU time and memory constraints, approximation and simplification regarding the geometry of the geological structure, the mineralogical assemblages and the injection period (up to 5 years) have been applied to the system, resulting in limited analysis of the estimated impacts.

The $\mathrm{CO}_{2}$ migration rate and the quantity of $\mathrm{CO}_{2}$ arriving as free gas and dissolving, firstly in the storage water and secondly in the water of the overlying aquifer, are calculated. $\mathrm{CO}_{2}$ dissolution into the Dogger aquifer induces a $\mathrm{pH}$ drop from about 7.3 to 4.9 limited by calcite dissolution buffering. Glauconite present in the Albian aquifer also dissolves, causing an increase of the silicon and aluminium in solution and triggering the precipitation of kaolinite and quartz around the intrusion point. A sensitivity analysis of the leakage rate according to the location of the leaky well and the variability of the petro-physical properties of the reservoir, the leaky well zone and the Albian aquifers is also provided.

Key-words $\mathrm{CO}_{2}$ geological storage, · well leakage, ·reactive transport modelling, water quality

\section{Introduction}

Within the context of Carbon dioxide Capture and geological Storage (CCS), the potential leakage of $\mathrm{CO}_{2}$ back into the atmosphere has been considered unavoidable in the long term but acceptable if it is small enough, i.e. less than $1 \%$ of the stored volume (Hepple and Benson 2003). $\mathrm{CO}_{2}$ leakage up through abandoned wells has been intensively studied using analytical or semi-analytical models and applied in the province of Alberta, Canada, where the density of wells is particularly high (Nordbotten et al. 2009 and references cited therein). These well-leakage models serve as inputs for certification framework and risk analysis (Bennion and Bachu 2005; Gasda et al. 2005; Celia et al. 2008; Oldenburg et al. 2009). Though this semi-analytical approach produces a tremendous computational saving method in comparison with numerical modeling technology 
(Class et al. 2009), the coupling with geochemical fluid rock interactions is not considered. To overcome such a limitation we propose to use the reactive transport code TOUGHREACT (Xu et al. 2001) to assess:

(i) the multiphase flow evolving during the injection phase including dissolution of the $\mathrm{CO}_{2}$ in the aqueous phase,

(ii) the leakage of the $\mathrm{CO}_{2}$ from a reservoir target to an overlying formation through a leakage zone approximated by a 1D porous media,

(iii) the mineral dissolution and precipitation due to $\mathrm{CO}_{2}$ intrusion in the system, the final objective: evaluating the potential changes in groundwater quality due to $\mathrm{CO}_{2}$ leakage from the saline aquifer formation and focusing on the acidification process only. Data for the study are taken from the Paris Basin geology using the carbonated Dogger formation as the $\mathrm{CO}_{2}$ reservoir target and the sandstone Albian formation as the overlying fresh water aquifer. The Albian aquifer of the Paris Basin is our study object because the Paris Basin contains deep saline formations identified as targets by the French national program of $\mathrm{CO}_{2}$ geological storage. The Paris Basin also relies heavily on freshwater aquifers for its drinking-water supply including deep freshwater resources of strategic importance like the Albian aquifer.

The major concerns for CCS in carbonated saline aquifers are the porosity changes of the minerals present. High dissolution rates may be expected because of the $\mathrm{CO}_{2}$ dissolution resulting in a $\mathrm{pH}$ decrease. Lagneau et al. (2005), using a single phase approach, have calculated high $\mathrm{pH}$ drops (down to 3) in the Dogger aquifer conducting to complete dissolution of calcite $1 \mathrm{~km}$ around the injection point after a 10000 - year simulation. André et al. (2007) showed that a multiphase approach would significantly reduce porosity changes of the carbonated system (Dogger formation) assuming no geochemical reactions 
occurred between the rock minerals and supercritical $\mathrm{CO}_{2}$. Cunningham et al. (2009) have drawn the same conclusions on a high dolomite aquifer situated in South Florida (USA).

Using Gulf Coast sandstones of the Frio formation in Texas, Xu et al. (2003) and $\mathrm{Xu}$ et al. (2005) have predicted very low porosity changes due to $\mathrm{CO}_{2}$ injection. They attribute this to the high level of quartz (inert to acidification) and a slow kinetic rate of aluminosilicate minerals. In a similar manner Audigane et al. (2007) have conducted numerical modelling of $\mathrm{CO}_{2}$ injection into an unconsolidated sandstone aquifer in the North Sea (Sleipner demonstration pilot, Norway) showing small mineral trapping and porosity modification after a 10000 year simulation.

Impacts of potential geochemical reactivity to $\mathrm{CO}_{2}$ intrusion into potable ground water have been investigated by Wang and Jaffe (2004) to assess the release of lead sulphide. The simplified rock mineralogy, used to simulate the impacted aquifer with a high volume fraction of Galena (in combination with calcite and quartz), causes the maximum contaminant level (MCL) for lead, defined by the U.S.A., to be exceeded. Kharaka et al. (2009) provided a complete analysis of the geochemical impact observed at the Frio-I brine pilot test in Texas, USA. They observed a strong $\mathrm{pH}$ decrease - down to 3 - accompanied with rapid dissolution of minerals, especially calcite and iron hydroxides, along with indications of corrosion of the pipe and well casing. Carroll et al. (2009) also conducted reactive transport modelling, to detect $\mathrm{CO}_{2}$ leaks in aquifers by changes in $\mathrm{pH}$ and carbonate chemistry, using the High Plains aquifer to represent a typical sedimentary aquifer overlying a $\mathrm{CO}_{2}$ deep storage reservoir. Smyth et al. (2009) used both laboratory experiments and field observations from the SACROC oilfield - used for enhanced oil recovery purposes - to assess the risk to fresh 
water resources from long term $\mathrm{CO}_{2}$ storage in geological formations. Chemical constituents measured in samples of the overlying aquifer suggested minor mixing with more saline water or co-produced oilfield brines.

Decreasing $\mathrm{pH}$ can also enhance the release of hazardous trace elements due to desorption from adsorption sites, mobilizing toxic trace metals or organic compounds (see Kharaka et al. (2006) observation at the Frio-I pilot site in Texas). Injection of $\mathrm{CO}_{2}$ at the ZERT Field site (Bozeman, Montana, USA) shows that the dissolution of carbonate minerals and desorption-ion exchange resulting from the lowered $\mathrm{pH}$ values is responsible for the increases in the concentration of solutes such as BTEX, metals solutes (Kharaka et al. 2010). However, the concentrations are significantly below the maximum contaminant levels.

Mobilisation of chemical components due to desorption is not the aim of our study. For this type of process we refer to Birkholzer et al. (2008), Zheng et al. (2009) and Apps et al. (2010) for a thermodynamic evaluation of hazardous trace elements. They used 38,000 groundwater quality analysis taken from the USGS National Groundwater Information System (NWIS) database.

In this study, we have simulated potential leakage through an abandoned well using the Dogger aquifer (Paris Basin, France) as the storage target (Brosse et al. 2007; Grataloup et al. 2009). The leaking well is in contact with an overlying freshwater aquifer (Albian formation). Despite the physical separation of the storage reservoir and the Albian aquifer, there is still concern that storage reservoirs may leak through abandoned wells and along faults. We describe here a particular case where the leakage of $\mathrm{CO}_{2}$ might occur by means of man-made pathways such as abandoned wells. Indeed, the $\mathrm{CO}_{2}$ plume will expand during 
injection and could come into contact with wells. When the $\mathrm{CO}_{2}$ stored in the Dogger aquifer at a depth of $\sim 1600$ m leaks upward, its thermodynamic state will change from a supercritical to a gaseous at the lower pressures encountered in the Albian aquifer ( $\sim 60 \mathrm{~m})$. Leakage would not only reduce the efficiency of carbon storage, but might also have a negative impact on groundwater quality. A sensitivity analysis, based on the analytical approach described above (Nordbotten et al. 2009), has also been supplied to assess the variability of our simulations concerning the $\mathrm{CO}_{2}$ leakage rate versus the location of the leaky well along with petro-physical property uncertainties of the studied area.

Simulation parameters are constrained by groundwater and deep saline chemistry, flow and lithology in the Albian and Dogger aquifers. Geochemical impacts on the water quality are assessed using TOUGHREACT for reactive transport modeling of the leakage with an appropriate data set for implementing the hydrogeological and hydro-geochemical properties of the 3D model. The final results of this study focus primarily on the dissolution of minerals present in the aquifer induced by the lowering of the $\mathrm{pH}$ as a direct result of the penetration of $\mathrm{CO}_{2}$ in the system.

\section{The case-study description}

\section{Hydrogeological and geochemical context}

The intracratonic Paris Basin (France) was the site of almost continuous subsidence and sedimentation during the Mesozoic Era. It is made up of a layer up to 3,000 $\mathrm{m}$ thick of indurated Triassic to Tertiary sediments resting on a basement (Guillocheau et al. 2000). This complex, multi-layered aquifer system provides two aquifers (Triassic and Dogger) suitable for large-scale $\mathrm{CO}_{2}$ storage in a deep 
saline aquifer. In this study, we consider $\mathrm{CO}_{2}$ injection into the Dogger aquifer and study the impact of leakage on the fresh groundwater in the Albian formation. The study area is located in the SE of the basin (Fig.1).

Fig.1

The aquifer investigated for $\mathrm{CO}_{2}$ storage is in the Middle Jurassic (Dogger) aquifer in the centre of the Paris Basin at a depth of 1500-2000 m. This aquifer, exploited for geothermal and petroleum resources, is composed mainly of carbonates. Sedimentary studies (Rojas et al. 1989) have shown that the most permeable facies, the Oolitic limestone, retains or even increases its initial porosity by fracturing and dissolution. The groundwater in the Dogger, recharged by meteoric water, flows from the east and southeast towards the centre of the basin. Wei et al. (1990) estimated (by modeling) the Darcy average horizontal velocity in the Dogger south of Paris to be around 0.33 m. $\mathrm{y}^{-1}$.

The confined Albian aquifer covers an area of about 75,000 $\mathrm{km}^{2}$ in the Paris Basin (Raoult et al. 1997). It is a sandy multi-layered aquifer. Vertical flow upward from the underlying Neocomian aquifer (up to $24 \%$ ) has been measured in the Paris area. In the area studied here, however, vertical flow is insignificant and not considered in the model. The Cenomanian Chalk aquifer overlying the Albian aquifer does not contribute to its recharge. It is composed mainly of quartz, glauconite, kaolinite, muscovite, carbonates (siderite, calcite, dolomite), phosphates, barite, and pyrite (Mégnien and Mégnien 1980). The groundwater in the Albian formation has several different chemical compositions depending on the origin of the recharge, with some common characteristics. Albian groundwater is anoxic with high concentrations of $\mathrm{Fe}$, a $\mathrm{pH}$ of around 7 and low mineral content $(0.3$ to $0.6 \mathrm{~g} / \mathrm{L})$. The Neocomian aquifer underlying the Albian aquifer, is characterized by high concentrations of $\mathrm{Na}$ and $\mathrm{Mg}$, as well as $\mathrm{F}$ and $\mathrm{Sr}$. The 
influence of Neocomian groundwater on the Albian groundwater has been observed northwest of Paris but not in the study area, which confirms the absence of vertical flow (Raoult et al. 1997).

\section{Leakage scenario}

Numerical modeling provides an alternative way to assess CCS risks that includes a better description of geological features and combines hydrological, thermal and geochemical processes. However, its performance is limited by mesh resolution and calculation times. Benchmark studies make it possible to evaluate code performance and precision. To date, two major studies conducted within the context of CCS have provided a pertinent status of code performance (Pruess et al. 2004; Class et al. 2009). Class et al. (2009) have directly addressed the context of leakage through abandoned wells, highlighting the performance and limitations of numerical modeling.

We use numerical modeling to simulate the effect of $\mathrm{CO}_{2}$ leakage on the quality of the groundwater in the Albian aquifer located above a hypothetical carbon dioxide storage reservoir (Dogger aquifer). The aquitard separating these two aquifers is assumed to be totally impermeable and the permeability and porosity of both aquifers are homogeneous and isotropic $\mathrm{CO}_{2}$ leaks through an abandoned well located $100 \mathrm{~m}$ from the injection well (Fig.2), as proposed in the benchmark study done by the University of Stuttgart (Class et al. 2009).

\section{Fig.2}

The potential hazards of $\mathrm{CO}_{2}$ leakage from the storage system must be precisely defined. Indeed, leakage can occur through various pathways such as abandoned 
wells and natural geological features (faults or fractures). It is important to determine which leakage scenario should be taken into account in order to consider a realistic and likely hypothesis.

We have considered a man-made leakage pathway such as an abandoned well. When the expanding $\mathrm{CO}_{2}$ plume reaches the well, $\mathrm{CO}_{2}$ can leak upward along various possible paths (Gasda et al. 2004): between the cement and the rock formation, through the cement, between the cement and the casing in a cased well, through the cylindrical space within the casing if the casing is corroded, and through cement plugs if they are damaged or degraded.

Modeling all leakage pathways would be far too complex to simulate correctly, especially considering the large scale of our model. Therefore, we simulate leakage with a $1 \mathrm{D}$ porous column at the rock-cement interface. This interface is a possible pathway due to well face deterioration when the well is being drilled and multiple stresses (pressure and temperature variations) when the well is in operation (Oldenburg 2007; Roegiers 2002).

\section{Modeling approach}

The numerical simulations were done using the TOUGHREACT code to handle 3D reactive flow and transport calculations (Xu and Pruess 2001). TOUGHREACT is a software package for modeling multiphase, multicomponent heat and mass flow and reactive transport in saturated and unsaturated porous media. An integrated finite difference spatial discretization scheme is used to solve mass and energy balance equations in both flow and reactive transport models. The resulting non-linear equations are solved by the Newton Raphson method. This simulator deals with thermal, hydrologeologic and chemical 
processes and is applicable to one, two and three dimensional geologic systems. TOUGHREACT is an extension of TOUGH2 V2 (Pruess 1991), which incorporates the fluid property module $\mathrm{ECO} 2 \mathrm{~N}$ (Pruess 2004) for $\mathrm{H}_{2} \mathrm{O}-\mathrm{CO}_{2}-\mathrm{NaCl}$ mixtures.

In response to numerical modeling performance and CCS objectives (steering a middle course between mesh resolution and calculation time), various modules written in FORTRAN have been developed to facilitate the execution and the preand post-processing of TOUGH2 and TOUGHREACT models (Chiaberge et al. 2009, Audigane et al. 2010). These modules are programmed to use ASCII input and output files coming directly from TOUGH2 or TOUGHREACT. They offer various possibilities for managing local grid refinement, mesh coarsening, grid block inactivation, as well as rock property allocation and boundary condition application.

\section{Geometrical model and mesh}

The Albian multilayer aquifer is represented as a homogeneous layer formation since the aquitards are not continuous (Vernoux et al. 1997) - a horizontal formation, $625 \mathrm{~m}$ deep, $80 \mathrm{~m}$ thick, with an area of $3 \times 3 \mathrm{~km}$. Injection of $\mathrm{CO}_{2}$ is simulated into the Dogger aquifer represented as a horizontal formation $1525 \mathrm{~m}$ deep, $30 \mathrm{~m}$ thick, with an area of $5 \times 5 \mathrm{~km}$. The formation rock-cement interface in the abandoned well is simulated as a 1D porous medium connecting the two aquifers, located $100 \mathrm{~m}$ away from the injection well, $820 \mathrm{~m}$ long, with a crosssectional area of $5 \times 5 \mathrm{~m}$.

To build the model, we created a 3D grid containing the storage aquifer, the aquitard domain, and the overlying aquifer. We then refined locally around the 
abandoned well for the entire domain and around the injection well inside the storage aquifer only. Finally, we removed all grid blocks within the aquitard domain. The final grid containing 5326 cells and associated local grid refinement is shown in Fig.3.

Fig.3

\section{$\mathrm{CO}_{2}$ thermodynamics of the system}

Pressure and temperature are initialized for the whole system with a specific geothermal gradient for each formation. Constant hydrostatic pressure is imposed on each side of the grid. Pressure and temperature gradients were applied to initiate calculations though simulations run in an isothermal mode. Temperature at the top of the Dogger formation corresponds to the isotherm measured in the study area (Brosse et al. 2007). For the Albian formation, the temperature was measured. The log temperature was based on geothermal gradients of $3{ }^{\circ} \mathrm{C}$ and 4 ${ }^{\circ} \mathrm{C} / 100 \mathrm{~m}$ for the Albian (Lemoine et al.1939) and Dogger (Michard et al.1988) aquifers, respectively (Fig.2). A hydrostatic pressure was initialized using a pressure value at the top of the Albian formation at 57 bar.

Using well log measurements, we plotted pressure and temperature conditions representative of the Dogger and Albian aquifers in the $\mathrm{CO}_{2}-\mathrm{P}-\mathrm{T}$ phase diagram space (Fig.4). To estimate thermodynamic changes in the $\mathrm{CO}_{2}$ during its upward migration, a linear path was calculated using typical geothermal and hydrostatic gradients of $3{ }^{\circ} \mathrm{C} / 100 \mathrm{~m}$ and $0.1 \mathrm{bar} / \mathrm{m}$, respectively, assuming a surface temperature of $12{ }^{\circ} \mathrm{C}$. These calculations show that the supercritical $\mathrm{CO}_{2}$ injected into the Dogger has changed into a gas by the time it reaches the depth of the Albian aquifer (Fig.4). 
Fig.4

These two states are represented by characteristic physical qualities such as viscosity and density. The density and viscosity of the injected $\mathrm{CO}_{2}$ are about 550 $\mathrm{kg} / \mathrm{m}^{3}$ and $0.04 \mathrm{mPa} . \mathrm{s}$ under the Dogger pressure and temperature conditions. They are $190 \mathrm{~kg} / \mathrm{m}^{3}$ and $0.02 \mathrm{mPa} . \mathrm{s}$ under the pressure and temperature conditions of the Albian aquifer domain (Span and Wagner 1996; Spycher et al. 2003; Spycher and Pruess 2005).

\section{Geochemistry of the system}

Our model's initial geochemical system is based on the equilibrium between the chemical composition of the aqueous phase and the mineralogical assemblage of the solid phase representative of the porous rock for each aquifer domain. We needed to develop a geochemical system characteristic of each aquifer, in agreement with measured data, describing the mineralogical and aqueous phase compositions of each medium. At this stage, all mineral dissolution and precipitation models are considered at equilibrium. All chemical elements that are likely to have a quantitative influence on dissolution or precipitation reactions must be taken into account. To constrain the geochemical model, an iterative procedure between modeling assessment and calibration with measured data found in the literature is needed. Various assumptions are made, depending on the initial geochemical characteristics of the three domains used to describe the geochemical system. The mineralogy of the Albian and Dogger formations was determined using Phreeqc (Parkhurst and Appelo. 1999). Calculations were done using the results of analyses of water from several wells (groundwater quality 
measurements) located in the study area in order to simulate a water composition similar to the mean of the observed chemical compositions depending on environmental conditions (Table 1).

Fig. 5 shows the relative proportions and concentrations of various elements in the Albian and Dogger aquifers. The calculated water speciation characterizes the state of equilibrium with respect to minerals (Fig.5). (See also Table 2 and Table 3 in appendix for quantitative details on water and mineral chemical compositions for each system). The leakage pathway defined as a 1D porous column has a chemical composition similar to that of the Albian aquifer for the aqueous phase, without any solid phase minerals.

\section{Table 1; Fig.5}

In the next step, calcite and siderite dissolution and precipitation are considered at local equilibrium while the dissolution and precipitation of other minerals are not, according to the database provided by Palandri and Kharaka (2004) (See Table 4 and Table 5 in appendix for the detailed description of the kinetic rate law used in this study).

\section{Multiphase flow}

The $\mathrm{CO}_{2}$ injection scenario entails multiphase flow in porous media because of the incompatibility of injected and native fluids. This multiphase flow is described by a generalized Darcy's law with relative permeability and capillary pressure correlations. Numerical models for predicting the fate of the injected $\mathrm{CO}_{2}$ also require information concerning the relative permeability of $\mathrm{CO}_{2}$ and brine capillary pressure. 
- Relative permeability characteristics in a $\mathrm{CO}_{2}-\mathrm{NaCl}_{2} \mathrm{H}_{2} \mathrm{O}$ system

Knowledge is lacking concerning multiphase flow data relevant to the operation of $\mathrm{CO}_{2}$ sequestration in geological formations. Although $\mathrm{CO}_{2}$ storage is an emerging field, there is little data available regarding the relative permeability and capillary pressure of $\mathrm{CO}_{2}-\mathrm{NaCl}-\mathrm{H}_{2} \mathrm{O}$ systems under in situ conditions. Bennion and Bachu (2005) have provided the most complete review of laboratory experiments of measurements on a carbonate and sandstone system in the Western Canada Sedimentary Basin.

Neither relative permeability nor capillary pressure data are available for the Albian aquifer. Considering the sandstone lithology of this aquifer, we decided to use a Van Genuchten model from Sleipner field parameters (sandy Utsira formation) to simulate multiphase flow (Fig.6). To provide a range of variability for the model chosen, we also plotted the data of Bennion and Bachu (2005) from the Ellerslie sandstone corresponding to the Albian Stage. The general trend of the two curves is fairly similar but the residual gas saturation value of 0.7 for the Ellerslie sandstone is much higher than the other $(0.2$, see Table 6$)$.

Outcrops of the Dogger formation were collected for a Lavoux limestone sample. Laboratory experiments were done to characterize multiphase flow (courtesy of JF Lombard from IFP, see Appendix of André et al. 2007). Data from several carbonate systems (Bennion and Bachu 2005) were plotted (Fig.6) for comparison. The concavity of the Lavoux limestone is the opposite of the others. This might be due to the fact that samples were collected at a depth much greater than that of the reservoir, which can modify the texture of the porous structure and the associated transport properties. We, therefore, decided to retain a Van Genuchten model with similar residual saturation for Lavoux limestone (Table 6) 
but changed the curvature of the model to better fit other deep carbonate systems (like the Wabamun carbonate from Bennion and Bachu 2005).

\section{Fig.6}

\section{- $\quad$ Capillary pressure in a $\mathrm{CO}_{2}-\mathrm{NaCl}_{2} \underline{\mathrm{H}}_{2} \underline{\mathrm{O} \text { system }}$}

A multiphase system includes a fundamental correlation between the wetting and the non-wetting phase saturation and capillary pressure, which enables the estimation of the migration of injected $\mathrm{CO}_{2}$. Fig.6 (c and d) shows the relationship between gas-aqueous capillary pressure head and the aqueous saturation.

As previously described with relative permeability and to provide a range of variability for the chosen model, we also plotted data of Bennion and Bachu (2006) from the Viking sandstone corresponding to the Albian-Santonian Stage in the Wabamun Lake area of the Alberta basin, Canada. The general trend of the two curves is comparable but the pore entry pressure (bubble point), corresponding to the minimum pressure required before $\mathrm{CO}_{2}$ starts invading the pore, for the Viking sandstone is much higher than Sleipner (Fig 6). For instance, these curves highlight rock type differences from a petrophysical point of view (effective permeability greater for Utsira formation).

Outcrops of the Dogger formation were collected for a Lavoux limestone sample. Laboratory experiments were done to characterize multiphase flow (courtesy of JF Lombard from IFP, see Appendix of André et al. 2007).

As stated previously, the differences between the curves might be due to the fact that samples were collected at a depth much greater than that of the reservoir, which can modify the texture of the porous structure and the associated transport properties. We therefore decided to retain a Van Genuchten model with parameters of Lavoux limestone (Table 6) for the carbonate system in this model, 
and a Van Genuchten model with parameters of Sleipner sandstone for the Albian formation.

\section{Presentation of the analytical models}

\section{$\mathrm{CO}_{2}$ plume extension model}

The analytical model for the $\mathrm{CO}_{2}$ plume extension used in this study was developed by Nordbotten and Celia (Nordbotten et al. 2004; Nordbotten et al., 2005; Nordbotten and Celia 2006). It is based on the standard multiphase extension of Darcy's law and allows the computation of the supercritical $\mathrm{CO}_{2}$ front thickness as a function of time and radial distance from the injection point (Fig.7). Behind the front there is a mixture of invading $\mathrm{CO}_{2}$ and brine at residual saturation. The solution was based on minimum energy principles for the case where buoyancy acts to segregate the fluids but does not otherwise play a significant role. It accounts for $\mathrm{CO}_{2}$ and brine solubilities and is limited to systems of relatively high injection rates compared to aquifer permeability.

\section{Fig.7}

The injection is assumed to take place through a fully penetrating well, with rates and aquifer slopes such that the aquifer can be approximated as horizontal for the injection period. As the horizontal length scale of the problem is far greater than the vertical scale, it is assumed that the flow is essentially horizontal. The brine$\mathrm{CO}_{2}$ interface, $\mathrm{h}$, is considered to be sharp; i.e. capillary pressure effects are ignored. The saturation points of $\mathrm{CO}_{2}$ in brine and brine in $\mathrm{CO}_{2}$ are held constant throughout the system.

The $\mathrm{CO}_{2}$ thickness (m) is given by (Equation 1) 


$$
\mathrm{h}(\mathrm{r}, \mathrm{t})=\frac{\mathrm{H}}{\lambda-1} \cdot\left(\sqrt{\frac{2 \cdot \lambda \cdot \gamma}{\chi(\mathrm{r}, \mathrm{t})}}-1\right)
$$

With:

$\lambda=\mathrm{kr} \cdot \frac{\mu_{\mathrm{w}}}{\mu_{\mathrm{c}}}, \chi(\mathrm{r}, \mathrm{t})=\frac{2 \cdot \pi \cdot \mathrm{H} \cdot \mathrm{e} \cdot(1-\mathrm{Slr}) \cdot \mathrm{r}^{2}}{\mathrm{Q}_{\mathrm{well}}{ }^{\mathrm{t}}}$ and $\gamma_{1}=\left[1+\frac{\beta_{1} \cdot \mathrm{Slr}}{(1-\mathrm{Slr}) \cdot\left(1-\beta_{2}\right.}\right]^{-1}$

With

$\mu_{\mathrm{c}} / \mu_{\mathrm{w}}: \mathrm{CO}_{2} /$ Brine viscosity (mPa.s)

kr: relative permeability (-)

e: porosity (-)

Slr: residual liquid phase saturation (-)

$\mathrm{H}$ : formation thickness (m)

$\mathrm{Q}_{\text {well: }}$ volumetric injection flow $\left(\mathrm{m}^{3} . \mathrm{s}^{-1}\right)$

$\mathrm{r}$ : distance from the injection well (m)

$\beta_{1} / \beta_{2}: \mathrm{CO}_{2} /$ Brine solubility (\%)

Equation (1) is valid if the gravity number:

With

$$
\Gamma=\frac{\left.2 \cdot \pi \cdot \rho_{\mathrm{w}}-\rho_{\mathrm{c}}\right) \cdot \mathrm{g} \cdot \mathrm{k} \cdot \mathrm{H}^{2}}{\mathrm{Q}_{\mathrm{well}} \mu_{\mathrm{W}}}<0.5
$$

$\rho_{\mathrm{c}} / \rho_{\mathrm{w}}: \mathrm{CO}_{2} /$ Brine density $\left(\mathrm{kg} \cdot \mathrm{m}^{-3}\right)$

$\mathrm{k}$ : formation permeability $\left(\mathrm{m}^{2}\right)$

(Equation 3):

$\chi-\left[1+\Gamma \cdot \lambda \cdot \chi \cdot\left(\frac{d}{d \chi} h^{2}\right)\right] \cdot \frac{2 \cdot \lambda}{\left[1+(\lambda-1) \cdot h^{\prime}\right]^{2}}+4 \cdot \Gamma \cdot \lambda \cdot \frac{1-h^{\prime}}{1+(\lambda-1) \cdot h^{\prime}} \cdot\left[h^{\prime}+\chi \cdot \frac{d}{d \chi} h^{\prime}+h^{\prime} \cdot \chi \cdot \frac{d^{2}}{d \chi^{2}} h^{\prime} \cdot\left(\frac{d}{d \chi} h^{\prime}\right)^{-1}\right]=0$

With $h^{\prime}=\frac{\mathrm{h}}{\mathrm{H}}, \frac{\mathrm{d}}{\mathrm{d} \chi} \mathrm{h}^{\prime} \neq 0$ and $\quad \int_{0}^{\mathrm{X} 0, \mathrm{~h}^{\prime}} \mathrm{h}^{\prime}(\mathrm{X}) \mathrm{dx}=2 \quad$ (Equations 4, 5 and 6)

If $\Gamma>0.5$, equation 3 must be resolved considering equations 4,5 and 6 


\section{Global pressure model}

The global pressure evolution during time and distance was assessed using Mathias et al. (2008) analytical solution. The governing equations for fluid pressure, $p$, and interface elevation, $h$, can be written as:

$$
\begin{aligned}
\frac{\partial}{\partial} \|\left(\mathrm{e} \cdot \rho_{\mathrm{c}}(\mathrm{H}-\mathrm{h} \|\right. & =-\frac{1}{\mathrm{r}} \cdot \frac{\partial}{\partial}\left[\mathrm{r} \cdot \rho_{\mathrm{c}} \cdot(\mathrm{H}-\mathrm{h}) \cdot \mathrm{q}_{\mathrm{c}}\right] \\
\frac{\partial}{\partial}\left|\mathrm{e} \cdot \rho_{\mathrm{W}} \cdot \mathrm{h}\right| & \left.=-\frac{1}{\mathrm{r}} \cdot \frac{\partial}{\partial} \mid \mathrm{r} \cdot \rho_{\mathrm{W}} \cdot \mathrm{h} \cdot \mathrm{q}_{\mathrm{W}}\right)
\end{aligned}
$$

Where the fluxes $\mathrm{q}_{\mathrm{c}}$ and $\mathrm{q}_{\mathrm{w}}$ are governed by the Forchheimer equations (Forchheimer 1901):

$$
\begin{aligned}
& \frac{\mu_{\mathrm{c}}}{\mathrm{k}} \cdot \mathrm{q}_{\mathrm{c}}+\mathrm{b} \cdot \rho_{\mathrm{c}} \cdot \mathrm{q}_{\mathrm{c}} \cdot\left|\mathrm{q}_{\mathrm{c}}\right|=-\frac{\partial}{\partial \mathrm{p}} \\
& \frac{\mu_{\mathrm{W}}}{\mathrm{k}} \cdot \mathrm{q}_{\mathrm{W}}+\mathrm{b} \cdot \rho_{\mathrm{W}} \cdot \mathrm{q}_{\mathrm{W}} \cdot\left|\mathrm{q}_{\mathrm{W}}\right|=-\frac{\partial}{\partial} \mathrm{p}
\end{aligned}
$$

With

$$
\begin{aligned}
& \mathrm{q}_{\mathrm{c}}: \mathrm{CO}_{2} \text { flux }\left(\mathrm{m}^{3} / \mathrm{s}\right) \\
& \mathrm{q}_{\mathrm{w}} \text { : Brine flux }\left(\mathrm{m}^{3} / \mathrm{s}\right) \\
& \text { b: Forchheimer parameter }\left(\mathrm{m}^{-1}\right)
\end{aligned}
$$

Considering the following initial and boundary conditions:

$$
\begin{array}{lll}
p=0, & r \geq 0, & t=0 \\
p=0, & r \rightarrow \infty, & t>0 \\
r q_{\mathrm{c}}=Q_{w} /(2 \pi H), & r=r_{\mathrm{w}}, & t>0
\end{array}
$$


$h=H$,

$$
r \geq 0
$$$$
t=0
$$

$h=H$,

$r \rightarrow \infty$,

$t>0$

$r q_{\mathrm{w}}=0$,

$r=r_{\mathrm{w}}$

$t>0$

And assuming that

- the fluids and geological formation are sufficiently rigid such that $c_{\mathrm{r}}, c_{\mathrm{c}}$, $\mathrm{c}_{\mathrm{w}}, \rho_{\mathrm{c}}, \mathrm{n}$, and $\rho_{\mathrm{w}}$ are essentially constant,

- non inertial flow $(b=0)$,

- the $\mathrm{CO}_{2}$ front moves much more slowly than the corresponding pressure wave (the difference between the two fluid compressibilities is small compared to the total compressibility of the brine aquifer).

The global pressure is, using the method of matched asymptotic expansion, given by equation 11 :

(Equation 11)

$$
\mathrm{p}=\frac{1}{2 \gamma} \cdot \mathrm{E} \cdot\left(\frac{\alpha \cdot \mathrm{x}}{4 \cdot \gamma}\right)+\frac{1}{2 \cdot \gamma} \cdot\left(\ln \left(\frac{\alpha \cdot \mathrm{x}}{4 \cdot \gamma}\right)+\kappa\right)+\left(\begin{array}{l}
-\frac{1}{2} \cdot \ln \left(\frac{\mathrm{x}}{2 \cdot \gamma}\right)-1+\frac{1}{\gamma}-\frac{1}{2 \cdot \gamma} \cdot\left(\ln \left(\frac{\alpha}{2 \cdot \gamma^{2}}\right)+\kappa\right) \text { if } \mathrm{x} \leq 2 \cdot \gamma \\
-\left(\frac{\mathrm{x}}{2 \cdot \gamma}\right)^{0.5}+\frac{1}{\gamma}-\frac{1}{2 \cdot \gamma} \cdot\left(\ln \left(\frac{\mathrm{x}}{2 \cdot \gamma^{2}}\right)+\kappa\right) \text { if } 2 \gamma<\mathrm{x}<\frac{2}{\gamma} \\
-\frac{1}{2 \cdot \gamma} \cdot\left(\ln \left(\frac{\alpha \cdot \mathrm{x}}{2 \cdot \gamma}\right)+\kappa\right) \text { if } \mathrm{x} \geq \frac{2}{\gamma}
\end{array}\right.
$$

With:

$$
\begin{aligned}
& { }_{\mathrm{D}}=\frac{\mathrm{r}}{\mathrm{r}_{\mathrm{W}}} \quad \mathrm{h}_{\mathrm{D}}=\frac{\mathrm{h}}{\mathrm{H}} \\
& \mathrm{x}=\frac{\mathrm{r}_{\mathrm{D}}^{2}}{{ }^{\mathrm{t}} \mathrm{D}}=\frac{2 \cdot \pi \cdot \mathrm{e} \cdot \mathrm{H} \cdot \mathrm{r}^{2}}{\mathrm{Q}_{\mathrm{Well}} \cdot \mathrm{t}} \quad \gamma=\frac{\mu_{\mathrm{c}}}{\mu_{\mathrm{w}}} \quad \alpha=\frac{\mathrm{Q}_{\mathrm{well}} \cdot \mu_{\mathrm{c}} \cdot \mathrm{c}_{\mathrm{r}}+\mathrm{c}_{\mathrm{w}}}{2 \cdot \pi \cdot \mathrm{H} \cdot \mathrm{k}}
\end{aligned}
$$

$\kappa \approx 0.5772$ Euler-Mascheroni constant $[-]$

$c_{\mathrm{r}}$ : Compressibility of geological formation $\left[\mathrm{Pa}^{-1}\right]$

$\mathrm{c}_{\mathrm{w}}$ : Compressibility of brine $\left[\mathrm{Pa}^{-1}\right]$ 
$\mathrm{i}_{\mathrm{D}}: \mathrm{D}$ means dimensionless

This analytical solution provides fast computation of the global pressure during the $\mathrm{CO}_{2}$ injection in the Dogger aquifer; it also has the advantage of not requiring an arbitrary radius of influence.

$\mathrm{CO}_{2}$ upward migration through the leakage zone

A very simplified approach was used to assess the $\mathrm{CO}_{2}$ upward migration through the leakage zone. Darcy's law was adapted according to the following equation 12

$$
\mathrm{Q}_{\mathrm{col}}(\mathrm{t})=\rho_{\mathrm{col}} \cdot \mathrm{S}_{\mathrm{pc}} \cdot \mathrm{k}_{\mathrm{m}} \cdot \frac{\mathrm{krc} \mathrm{CO} 2_{\mathrm{sat}}\left|\mathrm{r}_{\mathrm{pc}}, \mathrm{t}\right| \mid}{\mu_{\mathrm{col}}} \cdot\left(\frac{\mathrm{p}\left|\mathrm{r}_{\mathrm{pc}}, \mathrm{t}\right|-\mathrm{P}_{\text {Albian }}}{\mathrm{L}_{\mathrm{col}}}-\rho_{\mathrm{col}} \cdot \mathrm{g}\right)
$$

(Equation12)

With

$\rho_{\mathrm{col}}$ : mean $\mathrm{CO}_{2}$ density in the porous column $\left(\mathrm{kg} \cdot \mathrm{m}^{-3}\right)$

$\mu_{\mathrm{col}}$ : mean $\mathrm{CO}_{2}$ viscosity in the porous column (mPa.s)

$\mathrm{k}_{\mathrm{m}}$ : mean harmonic permeability at the Dogger and porous column interface

$\mathrm{k}_{\mathrm{m}}=2 /\left(1 / \mathrm{k}+1 / \mathrm{k}_{\mathrm{col}}\right)$, with $\mathrm{k}_{\mathrm{col}}:$ permeability of the porous column $\left(\mathrm{m}^{2}\right)$

$\mathrm{S}_{\mathrm{pc}}$ : porous column area $\left(\mathrm{m}^{2}\right)$

p: Porous column pressure (MPa)

P: Pressure at the base of the Albian aquifer (MPa)

$\mathrm{L}_{\mathrm{col}}$ : Porous column length $(\mathrm{m})$

krc: $\mathrm{CO}_{2}$ relative permeability (-)

$\mathrm{r}_{\mathrm{pc}}$ : distance between the injection well and the porous column (m)

$\mathrm{CO} 2_{\text {sat }}: \mathrm{CO}_{2}$ saturation at $\mathrm{r}_{\mathrm{pc}}$ and time $\mathrm{t}$ 
The $\mathrm{CO}_{2}$ saturation at the porous column level was calculated considering the thickness of the $\mathrm{CO}_{2}$ invading front (h) and a mixing layer thickness (Equation 13). A value of $16 \mathrm{~m}$ was obtained by calibration (i.e. comparison with the numerical results).

$$
\mathrm{CO}_{\text {sat }}=\frac{\mathrm{h} \cdot(1-\mathrm{Slr})}{\mathrm{H}_{\text {mix }}}
$$

We assume a decoupling between the $\mathrm{CO}_{2}$ leakage model in the porous column and the pressure and $\mathrm{CO}_{2}$ plume extension models, i.e. the $\mathrm{CO}_{2}$ leakage is negligible compared to the $\mathrm{CO}_{2}$ injection and that it will have an insignificant influence on the pressure distribution and the $\mathrm{CO}_{2}$ saturation in the Dogger aquifer.

Table 7 (Appendix) presents the parameters used in the analytical models.

\section{Simulation results}

\section{$\mathrm{CO}_{2}$ upward migration}

Injection is done at a rate of $12.7 \mathrm{~kg} / \mathrm{s}(0.4 \mathrm{Mt} / \mathrm{y})$ into the entire thickness of the Dogger formation, which is divided into three cells $(3 \mathrm{~kg} / \mathrm{s}$ per cell). We kept the system open by imposing constant pressure at the lateral boundaries of both aquifers. No regional flow is assumed during the first stage of the study. Since the maximum lateral extent is only $2.5 \mathrm{~km}$ from the injection point, the impact of a close boundary condition may play a role in the flow system (see discussion in 
Nordbotten et al. 2005). We therefore limited the scenario to a 5-year injection period.

According to this scenario, supercritical $\mathrm{CO}_{2}$ reaches the Albian formation after 90 days at a flow rate of $0.2 \mathrm{~kg} / \mathrm{s}$, which increases to $1.1 \mathrm{~kg} / \mathrm{s}$ after 5 years, at the end of the simulation (Fig.8). The $\mathrm{CO}_{2}$ gas intrusion is accompanied by liquid water, the flow rate of which decreases from $0.019 \mathrm{~kg} / \mathrm{s}$ after 90 days to 0.003 $\mathrm{kg} / \mathrm{s}$ after 5 years. After 5 years, the gas plume in the Dogger formation extends about $1500 \mathrm{~m}$ around the injection point (Fig.8), of which a few tens of meters are completely flushed by dried, supercritical $\mathrm{CO}_{2}$.

Fig.8

The gravity effect and the impact of vertical permeability are identified in both aquifers by the distribution of the $\mathrm{CO}_{2}$ dissolved in the brine. In the Dogger formation, the $\mathrm{CO}_{2}$ injection rate is high enough so that the gas phase (lighter than the brine) reaches the top of the formation, forming a reverse-bell-shaped pocket of gas in which $\mathrm{CO}_{2}$ dissolves. As the gas phase slowly migrates through the leaky zone and enters the Albian aquifer, the 1D vertical column contains only the gas. In a similar manner, the $\mathrm{CO}_{2}$-enriched liquid phase reaches the top of the Albian aquifer following the upward migration of the gas.

\section{Mineral reactivity}

The decrease in $\mathrm{pH}$ replicates the dissolved $\mathrm{CO}_{2}$ pattern and, after 5 years, the $\mathrm{pH}$ lowering zone extends about $300 \mathrm{~m}$ around the leaky well in the Albian formation

(Fig.9). The geochemical modifications on the system's aqueous and solid phases 
at the outlet of the leaky well in the Albian aquifer provide information on the correlation between the gas saturation and $\mathrm{pH}$ buffering (from 7.3 to 4.9) along with the dissolution of $\mathrm{CO}_{2}$ in the aqueous phase (from $3.010^{-3}$ to $1.3 \mathrm{~mol} / \mathrm{kgw}$ ).

\section{Fig.9}

The solution becomes under-saturated with most of the minerals in the Albian aquifer (Fig.10) due to the $\mathrm{pH}$ drop when $\mathrm{CO}_{2}$ dissolves. Such acidic conditions affect the dissolution of solid phases, causing modifications in the porosity, permeability and chemical composition of the formation.

\section{Fig.10}

Calcite and glauconite start to dissolve at the $\mathrm{CO}_{2}$ intrusion point, releasing calcium (from carbonate dissolution), iron, magnesium and potassium (due to silicate dissolution) into the solution (with a high and rapid impact on calcium and iron concentrations). Calcite dissolution (a consequence of the $\mathrm{pH}$ drop due to $\mathrm{CO}_{2}$ dissolution) occurs mainly above the intrusion point and implies a subsequent lack of buffering capacity.

There is a significant increase in the calcium concentration (from 1.3 to 31.6 $\mathrm{mmol} / \mathrm{kgw}$ ) and in the iron concentration (from 13 to $2,500 \mu \mathrm{mol} / \mathrm{kgw}$ ) in the $\mathrm{CO}_{2}$ intrusion zone. Iron is not, in fact, a health concern at concentrations normally measured in drinking water but taste and appearance are affected at levels below the drinking water standard (WHO). In France, the drinking water standard for iron is $3.6 \mu \mathrm{mol} / \mathrm{L}$. In the Albian aquifer, the groundwater exceeds this value and is currently treated. Siderite precipitates over time around the intrusion point, with little impact on the iron concentration. Moreover, aqueous sulfate concentration 
increases from $580 \mu \mathrm{mol} / \mathrm{kgw}$ to $1.4 \mathrm{mmol} / \mathrm{kgw}$ which can be associated with the pyrite dissolution (Fig.10).

Glauconite dissolution also causes an increase of the silicon and aluminum in solution, triggering the precipitation of kaolinite and quartz around the intrusion point. The release of potassium and magnesium does not involve any mineral phase precipitation. The silicon concentration increases from $210 \mu \mathrm{mol} / \mathrm{kgw}$ to $11.2 \mathrm{mmol} / \mathrm{kgw}$, whilst the potassium concentration increases from $15 \mu \mathrm{mol} / \mathrm{kgw}$ to $3 \mathrm{mmol} / \mathrm{kgw}$. Aluminium concentration in solution varies from $3.5810^{-9}$ to 1.3 $10^{-10} \mathrm{mmol} / \mathrm{kgw}$. This decrease can be associated with kaolinite precipitation which controls the aqueous $\mathrm{Al}$ concentration.

In TOUGHREACT the porosity change is directly calculated from changes in the solid volume due to mineral dissolution. In our simulation, porosity in the Albian sandstone slightly increases from $20 \%$ to $20.5 \%$ in the vicinity of the entry point. Matrix permeability changes are calculated from changes in porosity using the permeability ratios calculated from the Carman-Kozeny relation (Bear, 1972). In our model, permeability slightly increases from $1 \mathrm{D}$ to $1.1 \mathrm{D}$, resulting in a minor increase in the $\mathrm{CO}_{2}$ flow rate and the amount of $\mathrm{CO}_{2}$ in the system.

\section{Application: comparison with the numerical modelling - steady case}

In order to ascertain the relevance of the analytical models, we compare their results with the numerical results for spatial $\mathrm{CO}_{2}$ saturation and pressure changes 5 years after injection (Fig.11A), the temporal $\mathrm{CO}_{2}$ saturation and pressure changes in the Dogger aquifer below the porous column and the temporal $\mathrm{CO}_{2}$ leakage rate (Fig.11B).

Figure 11A confirms the impact of the close boundary condition on the spatial pressure distribution. The numerical results show a rebalance toward the initial 
pressure $(14.64 \mathrm{MPa})$ at the boundary limit, whereas the analytical pressure reaches $14.95 \mathrm{MPa}$ at $2500 \mathrm{~m}$ from the injection well and rebalances towards the initial pressure at a distance of around $100 \mathrm{~km}$. Nevertheless, this pressure gap has no influence on the $\mathrm{CO}_{2}$ leakage rate as the difference between the two pressures is only $8.2 \mathrm{kPa}$ at the porous column location $(100 \mathrm{~m}) 5$ years after injection (Fig.11B).

Fig.11

The distributions of spatial $\mathrm{CO}_{2}$ saturation (Fig.11A) in the numerical and analytical models are relatively close considering the assumptions of the analytical approach (sharp interface and constant $\mathrm{CO}_{2}$ saturation behind the $\mathrm{CO}_{2}$ front). 5 years after injection, the maximum extension of $\mathrm{CO}_{2}$ at the top of the Dogger aquifer is about $1500 \mathrm{~m}$ according to TOUGHREACT and $2250 \mathrm{~m}$ according to the analytical model. This disparity can be explained by the vertical discretization of the numerical mesh which considers three $10 \mathrm{~m}$ thick layers. With a more refined vertical discretization, numerical results would have shown a greater extension of the $\mathrm{CO}_{2}$ plume.

For the first 400 days, $\mathrm{CO}_{2}$ saturations in the Dogger aquifer below the porous column, calculated either numerically or analytically are very similar. However, a discrepancy increases with time, as the numerical $\mathrm{CO}_{2}$ saturation equilibrates to a value of 0.6 whereas the analytical saturation tends to the maximum $\mathrm{CO}_{2}$ saturation (0.8). This is due to the fact that unlike TOUGHREACT, the analytical approach does not account for a feedback between the $\mathrm{CO}_{2}$ leakage and the $\mathrm{CO}_{2}$ saturation. Nevertheless, this discrepancy has an acceptable impact on the $\mathrm{CO}_{2}$ leakage flow calculated analytically. The analytical $\mathrm{CO}_{2}$ leakage flow is at most 
$16.5 \%$ lower than the flow calculated numerically, and the difference is only 3.8 $\% 5$ years after injection $(1.028 \mathrm{~kg} / \mathrm{s}$ analytically, $1.069 \mathrm{~kg} / \mathrm{s}$ numerically).

In conclusion, the discrepancies observed between the two approaches, despite the analytical model assumptions $\left(\mathrm{CO}_{2} /\right.$ brine sharp interface, constant saturation behind the $\mathrm{CO}_{2}$ front, decoupling between the leakage and the transport models, etc.), are considered to be admissible as the main aim of the analytical approach is qualitative rather than quantitative. The idea is to stay reasonably close to the numerical results of the case study and to use the analytical approach for the sensitivity analysis presented in the following section.

\section{"Sensitivity analysis"}

A number of assumptions are now evaluated, in order to draw any meaningful conclusions from the study case previously presented as an example. The use of the analytical solution permits this "sensitivity analysis" to elude numerical time calculations. These assumptions include the distance between the injection well and the leaking well, porosity and permeability of the host rock and leaking path, an Genuchten parameters (residual liquid phase saturation and lambda) of the Dogger formation. The assumed relationship between capillary pressure and gas saturation is not taken into account in the analytical model and cannot be investigated here. How would these parameters affect the results observed i.e. the $\mathrm{CO}_{2}$ bubble extension in the Dogger fm or the $\mathrm{CO}_{2}$ leakage rate through Albian formation?

The sensitivity analysis performed is this study does not explore all the possible combinations between variables as a one-at-a-time method (OAT) was used, where the steady case scenario was considered as a baseline. The results are 
presented in (Fig.12) and the variability of parameters is detailed in Table 7. This OAT method was considered acceptable since the analytical models show a linear behaviour and the factors were taken to be independent from one another.

Fig.12

When the permeability of the Dogger varies from 0.01 to $1.031 \mathrm{D}$, we can observe two phenomenons. Indeed, for permeability between $0.01 \mathrm{D}$ to $0.1 \mathrm{D}$, the $\mathrm{CO}_{2}$ bubble extension in the Dogger formation stays constant $(1690 \mathrm{~m}$ from the injection well), the $\mathrm{CO}_{2}$ leakage rate increases from 0.061 to $0.256 \mathrm{~kg} / \mathrm{s}$, due to the fact that for this permeability range the $\mathrm{CO}_{2}$ bubble extension is described by equation 1 which does not depend on permeability (the gravity number defined in equation 2 is less than 0.5$)$. Whereas, from upper permeability values $(0.258 \mathrm{D} \leq$ $\left.\mathrm{K}_{\text {dogger }} \leq 1.031 \mathrm{D}\right)$, the $\mathrm{CO}_{2}$ extension varies and increases from $2230 \mathrm{~m}$ to 2450 $\mathrm{m}$, the $\mathrm{CO}_{2}$ leakage rate increases to $1.092 \mathrm{~kg} / \mathrm{s}$ and then decreases for permeability values of $1.031 \mathrm{D}$. The $\mathrm{CO}_{2}$ saturation shows the same profile as the $\mathrm{CO}_{2}$ leaking rate.

The increase of residual liquid phase saturation $(0.1 \leq$ Sls $\leq 0.6)$ involves the extent of the $\mathrm{CO}_{2}$ bubble. The $\mathrm{CO}_{2}$ leakage rate also increases before stabilizing for 0.54 and 0.6 values.

The leaking column permeability $\left(0.1 \mathrm{D} \leq \mathrm{K}_{\text {leaking column }} \leq 103.1 \mathrm{D}\right)$ and the Van Genuchten parameter $(\lambda)$ only influence the $\mathrm{CO}_{2}$ leakage rate. The increase of leaking column permeability involves a higher $\mathrm{CO}_{2}$ leakage rate and the increase of lambda (which accentuates the curvature of the relative permeability model) generates a lower $\mathrm{CO}_{2}$ leakage rate ( $\lambda$ steps only in the $\mathrm{CO}_{2}$ leakage model (equation 12)). 
As the Dogger porosity increases from 0.05 to 0.3 , the extension of the $\mathrm{C}_{2}$ in the formation and its leakage rate decrease due to greater available void volume.

The more the distance between the injection well and the leaking well is important (from 0.5 to $5000 \mathrm{~m}$ ), the smaller the $\mathrm{CO}_{2}$ saturation at the interface Dogger/leaking well. The $\mathrm{CO}_{2}$ leakage rate decreases according to the distance injection well-leaking well. For distances greater than $500 \mathrm{~m}$, the $\mathrm{CO}_{2}$ leakage rate becomes insignificant and the impact on Albian groundwater would be negligible.

This part explores the influence of the input parameters and the effect of input variation on the $\mathrm{CO}_{2}$ bubble extension and $\mathrm{CO}_{2}$ leakage rate.

If we are interested in the $\mathrm{CO}_{2}$ bubble extension in the host rock, Fig. 12 shows the importance of porosity value and liquid phase saturation (Sls) on it; it would be necessary to know with precision these in situ parameters corresponding to the host rock formation. Indeed, a $20 \%$ variation of porosity impacts the $\mathrm{CO}_{2}$ bubble extension by a few hundred meters.

Moreover, the $\mathrm{CO}_{2}$ leakage rate depends strongly on the distance between the injection and leaking wells, the permeability of the leaking column and lambda. It would be also necessary to know the parameters corresponding to overlying formations, wells and faults around the potential $\mathrm{CO}_{2}$ geological storage.

\section{Discussion}

The model presented in this paper will serve as a basis for future work on a more complete study of the impact of $\mathrm{CO}_{2}$ leakage on fresh groundwater. We discuss 
here the advantages and disadvantages of the model, focusing on the current limitations and possible future improvements.

The model takes into account three distinct zones of the system:

(i) the $\mathrm{CO}_{2}$ injection and storage aquifer,

(ii) the leakage path

(iii) the impacted aquifer.

The simulation of the $\mathrm{CO}_{2}$ plume for these three zones was performed in order to point out the interaction between the fluid and the host rock and to understand the origin and conditions of $\mathrm{CO}_{2}$ migration through the leaking zone. Previous numerical studies always focused, legitimately on the impacted aquifer, neglecting the injection aquifer as well as the leaky path connecting both systems. Our simulations allow a complete control of the injection zone along with the leakage point motivated by the inclusion (in the future) of additional chemical processes that affect the impacted aquifer. These include impurities coming from the capture phase such as NOx and SOx (Jacquemet et al. 2009) and chemical reactivity in the leakage zone.

The dissolution of calcite in the Dogger reaches about $37 \mathrm{~mol} / \mathrm{m}^{3}$ of the porous medium, compared to $120 \mathrm{~mol} / \mathrm{m}^{3}$ in the Albian aquifer. Indeed, the upward migration of $\mathrm{CO}_{2}$ through the leakage zone carries reactive acidic water to the fresh groundwater. Nevertheless, geochemical fluid-rock interactions in the leakage zone approximated as 1D porous media have been disregarded in the simulations, as a first rough estimation. Indeed, at this stage it remains difficult to identify exactly where $\mathrm{CO}_{2}$ would flow through the porous media. Different pathways have been identified and illustrated in the Figure 1 of Gasda et al. (2004). According the possible pathways, cement, well casing or caprock mineralogy is involved in the process of fluid-rock interactions. Incorporation of 
these geochemical processes would certainly overestimate the acidity of the inflowing $\mathrm{CO}_{2}$-rich fluid.

Boundary conditions, being a compromise between model extent-scale, numerical resolution and simulation time, might bias the analysis of the simulation results. To avoid the fact that the gas plume would eventually reach the boundary of the model, injection was simulated for only 5 years. Another model, having a boundary extending $25 \mathrm{~km}$ from the injection point and a 20 -year $\mathrm{CO}_{2}$ flux, has also been developed (but is not presented here). With this model, the dissolved $\mathrm{CO}_{2}$ spreads up to $2.5 \mathrm{~km}$ around the intrusion point and the leakage rate is similar to that of the model presented here. The required simulation time being much longer, it was not possible to run a fully coupled reactive transport model for such a large-scale model. Moreover, the comparison with the numerical and analytical modeling shows an interesting association to solve numerical pressure boundary condition problems as well.

Whereas carbonate dissolution due to the formation of an acidic plume from leakage of $\mathrm{CO}_{2}$ has been intensively studied and described, a discussion about the glauconite (Phyllosilicate group) dissolution mechanism, which plays a prominent role in Albian chemical impact, is necessary. Indeed, the glauconite dissolution rate was estimated by Palandri and Kharaka (2004) and this assumes that dissolution is fast enough so that the glauconite is rapidly in equilibrium with a fast release of iron and silicon, which triggers the precipitation of kaolinite and quartz around the intrusion point. This also influences the impact on the water quality.

Key controls of mechanism and hence rates of the oxidation of pyrite remain extremely complex and poorly understood (Rimstidt and Vaughan 2002). A very small quantity of gypsum precipitation has been observed in laboratory 
experiments conducted on sandstones of the saline aquifer of the Rio Bonito Formation, Paranà Basin in Brazil, suggesting pyrite oxidation though it was not verified in the numerical modeling (Ketzer et al. 2009). In our simulation, we allow gypsum to precipitate though simulations predict a saturation index for the solution slightly under-saturated with gypsum without preventing the sulfur release. We could suppose that the simulation time is too short to observe any formation of sulfate minerals like gypsum and an impact on aqueous sulfate concentration.

Zheng et al. (2009), Wang and Jaffe (2004) have evaluated the impact of $\mathrm{CO}_{2}$ leakage from deep geological storage on potable water quality and, more precisely, on the mobilization of hazardous trace elements such as lead and arsenic. Associated with a decrease in $\mathrm{pH}$ due to $\mathrm{CO}_{2}$ migration, some of the minerals play a major role in the final aqueous concentration of these elements. Arsenic is a concern in the release of trace elements associated with pyrite dissolution. Apps et al. (2010) show that the presence of $\mathrm{CO}_{2}$ disturbs solubility equilibria and that the solubility of arsenian pyrite increases significantly with the partial pressure of $\mathrm{CO}_{2}$. For this geochemical system the redox state is dominantly controlled by the pyrite buffer at a given $\mathrm{pH}$.

Since we used an earlier version of TOUGHREACT, this surface mechanism was not included in our model. Other references broaden the importance of this process. Smith et al. (1995) developed surface complexation models, such as the triple layer model, which investigate the metal adsorbing ability of an aluminosilicate mineral and, more precisely, glauconite. Finally, adsorption by surface complexation is a key process with respect to the transport and mobility of heavy metals or other hazardous constituents. Correlation between adsorption and the $\mathrm{CO}_{2}$ leakage plume will alter the water chemistry. It is widely accepted that 
the adsorption of ions on minerals is influenced by a variety of parameters such as $\mathrm{pH}$, type and speciation of the ion involved and competition between different ions (Dzomback and Morel 1990; Bradl 2004; Birkholzer et al. 2008). The surface phenomenon must be included in the following stages of this work if simulation is to be a sensitive monitoring technique.

\section{Conclusion}

A modeling study of the geochemical impact on fresh groundwaters following the introduction of $\mathrm{CO}_{2}$ during geological storage was conducted using multiphase reactive transport simulations. Different motives have fed this study. The model uses the carbonate saline Dogger aquifer in the Paris Basin as the storage reservoir and the Albian formation as the fresh groundwater aquifer. The Jurassic Dogger formation has been intensively used for geothermal purposes and is now under consideration as a site for the French national program of reducing greenhouse gas emissions and $\mathrm{CO}_{2}$ geological storage. Albian sandstone, situated above the Dogger limestone is a major strategic potable water aquifer. To focus this work on the risks related to $\mathrm{CO}_{2}$ leaks, an unfavorable scenario, in which the $\mathrm{CO}_{2}$ penetration into fresh groundwater, is willfully provoked. A leaky well placed 100 $\mathrm{m}$ away from the injection reservoir allows $\mathrm{CO}_{2}$ to reach the overlying formation impacting the chemical composition of the fresh groundwater Albian aquifer. The leakage path way up through an abandoned well is represented as a $1 \mathrm{D}$ porous medium, corresponding to the cement-rock formation interface. The $\mathrm{CO}_{2}$ injected at a rate of $12.7 \mathrm{~kg} / \mathrm{s}(0.4 \mathrm{Mt} / \mathrm{year})$ reaches the Albian aquifer after 90 days of injection. The gas plume in the Dogger formation extends up to $1.5 \mathrm{~km}$ from the 
point of injection after 5 years. The upward migration of $\mathrm{CO}_{2}$ at a rate of $1.1 \mathrm{~kg} / \mathrm{s}$ is accompanied by fresh water at a rate of $0.03 \mathrm{~kg} / \mathrm{s}$ at the end of the simulation. The $\mathrm{CO}_{2}$ injected in a supercritical state in the Dogger reaches the Albian aquifer in a gaseous state. Major mechanisms such as mineral dissolution in the fresh water are triggered by $\mathrm{CO}_{2}$ dissolution (regardless of the $\mathrm{CO}_{2}$ state: sub-critical or super-critical)

Though the release of trace elements like lead or arsenic is of a major concern for shallow groundwater chemical integrity, the principal geochemical process simulated in this study is the acidification of groundwaters (buffered from $\mathrm{pH} 7.3$ to 4.9) due to $\mathrm{CO}_{2}$ dissolution, inducing the dissolution of minerals in the Albian formation and the release of chemical elements. The zone impacted by dissolved $\mathrm{CO}_{2}$ covers a radius of $0.3 \mathrm{~km}$, whereas gaseous $\mathrm{CO}_{2}$ occurs only above the intrusion point. Calcite and glauconite dissolution occurs mainly above the intrusion point. A significant increase is observed in the calcium concentration from 1.3 to $31.6 \mathrm{mmol} / \mathrm{kgw}$ and in the iron concentration from 1.3 to 2,500 $\mu \mathrm{mol} / \mathrm{kgw}$ at the $\mathrm{CO}_{2}$ intrusion point. Beyond this zone, the model predicts an average geochemical reactivity similar with one order of magnitude smaller concerning dissolution and precipitation rate. Specific attention is paid to iron, high concentrations of which are present in the initial geochemical aqueous system.

A sensitivity analysis, performed on multiphase flow without considering any chemical fluid rock interaction in the system, is also provided to assess the variability of the $\mathrm{CO}_{2}$ leakage rate according the location of the leaky well, the petro-physical properties of the porous rock and fluid flow.

This model constitutes a starting point for future improvements focusing on the interplay between flow and geochemical interaction. The assessment of impact of 
$\mathrm{CO}_{2}$ intrusion to fresh groundwater quality was predicted for acidification processes and the mineral alterations associated. This 3D model will serve as a basis for including other mechanisms such as co-precipitation and sorption of hazardous constituents which are crucial for improving the analysis of the impact of $\mathrm{CO}_{2}$ leakage during storage on shallow fresh groundwater quality.

\section{Appendices}

Table 2 to Table 7

\section{Acknowledgements}

The authors wish to thank Moïse Gergaud and Angus Cunningham-Burley for reading an earlier version of the manuscript. This study was financed by BRGM under the research project dedicated to numerical modeling for the development of $\mathrm{CO}_{2}$ geological storage.

\section{References}

André, L., Audigane, P., Azaroual, M., Menjoz, A.: Numerical modelling of fluid-rock chemical interactions at the supercritical $\mathrm{CO}_{2}$-liquid interface during $\mathrm{CO}_{2}$ injection into a carbonate reservoir, the Dogger aquifer (Paris Basin, France) Energy Conversion and Management, 48(6), 1782-17972007 (2007)

Apps, J.A, Zheng, L., Zhang, Y, Xu, T.: Evaluation of potential changes in groundwater quality in response to $\mathrm{CO}_{2}$ leakage from deep geologic storage, Transport in Porous Media, pp.215246 (2010)

Audigane, P., Gaus, I., Czernichowski-Lauriol, I., Pruess, K., Xu, T.: Two dimensional reactive transport modelling of $\mathrm{CO}_{2}$ injection in a saline aquifer at the Sleipner site, North Sea. American Journal of Science 307, 974-1008 (2007)

Audigane, P. Chiaberge, Ch.; Mathurin, F.; Picot-Colbeaux, G.; Lions, J.: A workflow for handling heterogeneous 3D models with the TOUGH2 family of codes: Applications to numerical modeling of $\mathrm{CO}_{2}$ geological storage, Transport in Porous Media, Special Issue, ToughSymposium 2009, this issue. (2010)

Bachu, S., Bennion, B.: Effects of in situ conditions on relative permeability characteristics of $\mathrm{CO}_{2}$-brine systems. J. Environ. Geol (2007) 
Batzle, M., Wang Z.: Seismic properties of pore fluids. Geophysics, 57, pp. 1396-1408. (1992)

Bear, J.: Dynamics of Fluids in Porous Media. Published by American Elsevier. New York, NY (1972)

Bennion, B. and Bachu, S.: Relative permeability characteristics for supercritical $\mathrm{CO}_{2}$ displacing water in a variety of potential sequestration zones in the western Canada sedimentary basin, SPE 95547 (2005)

Bennion, B. and Bachu, S.: Supercritical $\mathrm{CO} 2$ and H2S-Brine drainage and imbibition relative permeability relationships for intergranular sandstone and carbonate formations, SPE 99326 (2006)

Birkholzer, J., Apps, J.A., Zheng, L., Zhang, Y., Xu, T., Tsang, C.-F.: Research project on $\mathrm{CO}_{2}$ geological storage and groundwater resources: water quality effects caused by $\mathrm{CO}_{2}$ intrusion into shallow groundwater. Lawrence Berkeley National Laboratory Technical Report, LBNL-1251E, 450 p. (2008).

Bradl, H.B.: Adsorption of heavy metal ions on soils and soils constituents. Journal of Colloid and Interface Science, 277, 1-18. (2004)

Brosse, É., Hasanov, V., Bonijoly D., Garcia D.: The PICOREF project : Selection of geological sites for pilot $\mathrm{CO}_{2}$ injection and storage in the Paris Basin, 1st French-German Symposium on Geological Storage of $\mathrm{CO}_{2}$, Potsdam, June 21-22, pp 36-37 (2007)

Carroll, S., Hao, Y., Aines, R.: Transport and detection of carbon dioxide in dilute aquifers, Energy Procedia 1, pp. 2111-2118 (2009)

Celia, M.A., Nordbotten, J.M., Bachu, S., Dobossy, M. and Court, B.: Risk of leakage versus depth of injection in geological storage. In: Proceedings of the GHGT-9 Conference, Washington, DC. (2008)

Chiaberge, Ch., Audigane, P.: Manuel d'utilisation des outils de pre et post processing pour la modélisation de stockage géologique de $\mathrm{CO}_{2}$ avec les logiciels TOUGH. Brgm Report RP57457, 50 pp. (2009)

Class, H., Ebigbo, A., Helmig, R., Dahle, H. K., Nordbotten, J. M.: A benchmark study on problems related to $\mathrm{CO}_{2}$ storage in geologic formations, Computers and Geosciences, DOI $10.1007 / \mathrm{s} 10596-009-9146-\mathrm{x}(2009)$

Cunningham, J. A., Okwen, R. T., Thomas, M. W., Trotz, M. A., Stewart, M.: Expected $\mathrm{CO}_{2}$ water-rock interactions and changes in formation porosity in a deep saline aquifer in Florida, United States. American Geophysical Union, 2009 Fall Meeting, San Francisco, California, USA, 12/14/09. (2009)

Duan, ZH., Moller, N. and Weare, J. H.: Molecular dynamics simulation of PVT properties of geological fluids and a equation of state of nonpolar and weakly polar gases up to $2000 \mathrm{~K}$ and 20,000 bar, Geochim. Cosmochim. Acta (1992)

Dzombak, D.A. and Morel, F.M.M.: Surface Complexation Modeling.John Wiley\& Sons, New York, 393 pp. (1990) 
Elderling, B., Nicholson, R.V., Scharer, J.M.: A combined kinetic and diffusion model for pyrite oxidation in tailings: a change in controls with time. Journal of Hydrology, pp. 47-60 (1993)

Forchheimer, P.: Wasserbewegung durch Boden. Z. Ver. Deutsch Ing. 45, 1782-1788 (1901)

Gasda, S., Bachu, S and Celia, M A.: Spatial characterization of the location of potentially leaky wells penetrating a deep saline aquifer in a mature sedimentary basin, Environmental Geology 46:707-720, DOI 10.1007/s00254-004-1073-5 (2004)

Gaus, I., Audigane, P., André, L., Lions, J., Jacquemet, N., Durst,P, Czernichowski-Lauriol I., Azaroual, M.: Geochemical and solute transport modeling for $\mathrm{CO}_{2}$ storage, what to expect from it?, International journal of greenhouse gas control, IJGGC-90, pp. 21 (2008)

Gleisner, M.; Herbert, R., Frogner Kockum, P.: Pyrite oxidation by Acidithiobacillus ferrooxidans at various concentrations of dissolved oxygen. Geochemical geology, pp. 16-29 (2005)

Grataloup S, Bonijoly, D, Brosse, E., Dreux, R, Garcia, D, Hasanov, V., Lescanne, M, Renoux, P., Thoraval, A.: A site selection methodology for $\mathrm{CO}_{2}$ underground storage in deep saline aquifers: case of the Paris Basin. Energy procedia. GHGT-9, pp. 2929-2936 (2009)

Guillocheau, F., Robin, C., Allemand, P. et al.: Meso-Cenozoic geodynamic evolution of Paris Basin: 3D stratigraphic constraints. Geodyn. Acta vol. 13: pp. 189-246 (2000)

Hepple, R. P., and Benson, S. M.: Implication of surface seepage on the effectiveness of geological storage of carbon dioxide as a climate change mitigation strategy. In Proceedings of the Sixth International Greenhouse Gas Technologies Conference, Kyoto, Japan, October 1-5, 2002; Gale, J., Kaya, Y., Eds.; Pergamon; Vol. I, pp 261-266 (2003)

Jacquemet, N., Le Gallo, Y., Estublier, A., Lachet, V., von Dalwigk, I., Yan, J., Azaroual, M., Audigane, P.: $\mathrm{CO}_{2}$ streams containing associated components-A review of the thermodynamic and geochemical properties and assessment of some reactive transport codes Energy Procedia, Volume 1, Issue 1, February 2009, Pages 3739-3746( 2009)

Kharaka, Y.K., Thordsen, J.J., Hovorka, S.D., Nance, S.H., Cole, D.R.: Potential environmental issues of $\mathrm{CO}_{2}$ storage in deep saline aquifers: Geochemical results from the Friot-I brine pilot test, Texas, USA., Applied Geochemistry 24 1106-1112(2009)

Kharaka, Y.K., Cole, D.R, Thordsen, J.J., Kakouros, E., Nance, H.S.: Gas-water- rock interaction in sedimentary basins; $\mathrm{CO}_{2}$ sequestration in the Frio Formation, Texas, USA. Journal of Geochemical Exploration, volume 89, issues 1-3, pp. 183-186 (2006)

Kharaka, Y.K, Thordsen, J.J, Kakouros, E., et al.: Changes in the chemistry of shallow groundwater related to the 2008 injection of $\mathrm{CO} 2$ at the ZERT field site, Bozeman, Montana. Environmental Earth Sciences, Volume 60, Issue 2, pp. 273-284 (2010)

Ketzer, J.M., Iglesias, R., Einlift, S., Dullius, J., Ligabue, R., De Lima, V. : Water-rock- $\mathrm{CO}_{2}$ interactions in saline aquifers aimed for carbon dioxide storage: Experimental and numerical modeling studies of the RIO Bonito Formation (Pemrian), southern Brazil, Applied Geochemistry pp. 760-767. (2009)

Knauss, K. and Wolery, T.: Muscovite dissolution kinetics as a function of $\mathrm{pH}$ and time at $70^{\circ} \mathrm{C}$. Geochemica et Cosmochimica Acta, V. 53, pp. 1493-1501 (1989) 
Lagneau V, Pipart A, Catalette H.: Reactive transport modelling of $\mathrm{CO}_{2}$ sequestration in deep saline aquifers. Oil Gas Sci Technol - Rev IFP (2005);60(2):231-47.

Lemoine,P., Humery, R; Soyer, R.: Les forages profonds du Bassin de Paris La nappe artésienne des Sables Verts, Extrait des Mémoires du Museum d'Histoire naturelle, Tome XI, (1939)

Mathias, S.A., Hardisty, P.E., Trudell, M.R., Zimmerman, R.W.: Approximate solutions for pressure buildup during $\mathrm{CO} 2$ injection in brine aquifers. Transp. Porous Media. doi:10.1007/s11242-008-9316-7. (2008).

Meehan :A correlation for water compressibility, Petroleum Eng (1980)

Mégnien, C., Mégnien, L.: Synthèse géologique du Bassin de Paris. Stratigraphie et paléogéographie. Mémoire BRGM n¹01-102-103, Orléans, France (1980)

Michard, G. and Bastide, J.-P.: Etude géochimique de la nappe du Dogger du Bassin Parisien. Geochemistry of the water table in the Dogger of the Paris basin, J. Volcanol. Geotherm. Res., 35: 151-163 (1988)

Nagy, K.L.: Dissolution and precipitation kinetics of sheet silicates, chemical weathering, Rates of silicate minerals, V.31, pp. 291-351 (1995)

Nordbotten, JM., Celia, M.A. and Bachu, S.:Analytical solutions for leakage rates through abandoned wells. Water Resour. Res.,40 (2004)

Nordbotten, J.M., Celia, M.A. and Bachu, S.:Injection and storage of CO2 in deep saline aquifers: Analytical solution for $\mathrm{CO} 2$ plume evolution during injection. Transp. Por. Med., 58 pp., 339-360. (2005)

Nordbotten, J.M. and Celia, M. A.: Similarity solutions for fluid injection into confined aquifers. Journal Fluid Mechanics, 561, pp. 307-327 (2006)

Nordbotten, JM; Kavetski, D, Celia, MA; Bachu, S.: Model for $\mathrm{CO}_{2}$ leakage including multiple geological layers and multiple leaky wells, Environmental Science \& Technology, Vol. 43, pp 743-749 (2009)

Numbere D., Brigham, W.E., Standing, M.B.: Correlations for physical properties of petroleum reservoir brines, PRI Report, Stanford University (1977)

Oldenburg, C.M.: Joule-Thomson cooling due to $\mathrm{CO}_{2}$ injection into natural gas reservoirs, Energy Conversion and Management 48 (2007) 1808-1815 (2007)

Oldenburg, C.M., Bryant, S.L., and Nicot, J-Ph.: Certification framework based on effective trapping for geologic carbon sequestration, International Journal of Greenhouse Gas Control, Vol. 3, pp 444-457 (2009)

Palandri, J., Kharaka, Y.K.: A compilation of rate parameters of water-mineral interaction kinetics for application to geochemical modeling. US Geological Survey Open File Report 20041068, 64 p (2004)

Parkhurst, D.L. and Appelo, C.A.J.: User's guide to PHREEQC (Version 2)— A computer program for speciation, batch-reaction, one-dimensional transport, and inverse geochemical calculations: U.S. Geological Survey Water-Resources Investigations Report 99-4259, 312 $\mathrm{p}(1999)$

Phillips, S.L., Igbene, A., Fair, J.A., Ozbek, H. and Tavana , M.: A Technical Databook for Geothermal Energy Utilization. Lawrence Berkeley Laboratory Report 12810 (1981) 
Pruess, K.: TOUGH2 - a general-purpose numerical simulator for multiphase fluid and heat flow: Lawrence Berkeley Laboratory Report LBL-29400, Berkeley, California (1991)

Pruess, K, Garcia, J, Kovscek, T, Oldenburg, C, Rutqvist, J, Steefel, C and Xu, T.: Code intercomparison builds confidence in numerical simulation models for geologic disposal Of $\mathrm{CO}_{2}$, Conference Information: 6th International Conference on Greenhouse Gas Control Technologies, 1-4 Oct. 2002, Kyoto Japan, Energy, Vol: 29, Issue: 9-10, pp: 1431-1444 (2004)

Raoult, Y., Boulègue, J., Lauverjat, J., Olive, P.: Geochemistry of the Albian aquifer in the Paris Basin area contributes to understanding complex hydrogeological behaviour. Comptes Rendus de l'Académie des Sciences - Series IIA - Earth and Planetary Science, vol 325, $n^{\circ} 6$, pp. 419-425 (1997)

Rimstidt, J., Vaughan, D. : Pyrite oxidation : a state of the art assessment of the reaction mechanism, Geochimica et Cosmochimica Acat, Vol. 67, No 5, pp. 873-880 (2003)

Roegiers, J.C.: Well modelling: an overview, Oil \& Gas Science and Technology - Rev. IFP, Vol. 57 (2002), No. 5, pp. 569-577 (2002)

Rojas, J., Giot, D., Le Nindre, Y.-M, Criaud, A., Fouillac, C. et Lambert, M.: Caractérisation et modélisation du réservoir géothermique du Dogger Bassin Parisien, France. Rapport Final. BRGM IRG SGN 89 (1989)

Saripalli, K. P., Meyer, P. D., Bacon, D.H., Freedman, V. L.: Changes in hydrologic properties of aquifer media due to chemical reactions: a review. Critical Reviews in Environmental Science and Technology, pp. 311-349 (2001)

Smith, E., Lu, W., Vengris, T., and Binkiene, R.: Sorption oh heavy metals by Lithuanian glauconite. Water Research, pp. 2883-2892 (1996)

Smyth, R.C., Hovorka, S.D., Lu, J., Romanak, K.D., Partin, J.W., Wong, C.: Assessing risk to fresh water resources from long term $\mathrm{CO}_{2}$ injection-laboratory and field studies. Energy Procedia, Vol. 1, Issue 1, pp. 1957-1964, (2009)

Span, R. and Wagner, W.: A New Equation of State for Carbon Dioxide Covering the Fluid Region from the Triple-Point Temperature to $1100 \mathrm{~K}$ at Pressures up to $800 \mathrm{MPa}$, J. Phys.Chem. Ref. Data, Vol. 25, No. 6, pp. 1509 - 1596 (1996)

Spycher, N., Pruess, K. and Ennis-King, J.: $\mathrm{CO}_{2}-\mathrm{H} 2 \mathrm{O}$ Mixtures in the Geological Sequestration of $\mathrm{CO}_{2}$. I. Assessment and Calculation of Mutual Solubilities from 12 to $100{ }^{\circ} \mathrm{C}$ and up to 600bar, Geochim. Cosmochim. Acta, Vol. 67, No. 16, pp. 3015 - 3031, doi:10.1016/S00167037(03)00273-4 (2003))

Spycher, N. and Pruess, K.: $\mathrm{CO}_{2}-\mathrm{H}_{2} \mathrm{O}$ Mixtures in the Geological Sequestration of ${ }_{2}$. II.Partitioning in Chloride Brines at $12-100{ }^{\circ} \mathrm{C}$ and up to 600 bar, Geochim. Cosmochim. Acta, Vol. 69, No. 13, pp. 3309-3320,doi:10.1016/j.gca.2005.01.015 (2005)

Tester, J.W, Worley, G.W, Robinson, B.A, Grisby, C.O and Feerer, J.L. : Correlating quartz dissolution kinetics in pure water from 25 to $625^{\circ} \mathrm{C}$. Geochemica et Cosmochimica Acta, V.58, pp.2407-2420 (1994)

Van Genuchten, M.Th.: A clodes-form equation for predicting the hydraulic conductivity of unsatured soils.Soil Sci. Soc., v.44, pp.892-898 (1980) 
Vernoux, J.F., Maget, P., Afzali, H., Blanchin, R., Donsimoni, M., Vairon, J.: Synthèse hydrogéologique du Crétacé inférieur du Bassin de Paris, rapport BRGM DSGR/IDF R39702, 93p (1997)

Wang, S. Jaffe, P.R.: Dissolution of a mineral phase in potable aquifers due to $\mathrm{CO}_{2}$ releases from deep formations; effect of dissolution kinetics. Energy Conversion and Management, v.45, pp. 2833-2848 (2004)

Wei, H.F., Ledoux, E. and Marsily, G.de: Regional modelling of groundwater flow and salt and environmental tracer transport in deep aquifers in the Paris Basin. J. Hydrol., vol 120, pp. 341-358 (1990)

Xu, T., Pruess, K.: Modeling multiphase non-isothermal fluid flow and reactive geochemical transport in variably saturated fractured rocks: 1. Methodology: American Journal of Science, v. 301, p. 16-33. (2001)

Xu, T., Apps, J.A., Pruess, K.: Reactive geochemical transport simulation to study mineral trapping for $\mathrm{CO}_{2}$ disposal in deep Arenaceous Formations. J. Geophys. Res.108 (B2) (2003)

Xu, T., Apps, J.A., Pruess, K.: Mineral sequestration in a sandstone-shale system, Chemical Geology 217 (2005) 295-318

Zheng, L., Apps, J.A., Zhang, Y., Xu, T., Birkholzer, J.T.: On mobilization of lead and arsenic in groundwater in response to $\mathrm{CO}_{2}$ leakage from deep geological storage, Chemical Geology, In Press, Corrected Proof, Available online 14 September 2009, doi:10.1016/j.chemgeo (2009)

\section{List of caption figures:}

Fig. 1 Map of the studied area (BRGM) Grataloup et al. (2009)

Fig. 2 Diagram representing the simulated leakage scenario based Class et al. (2009) with initial pressure and temperature gradient

Fig. 3 3D mesh representation for modeling leakage from the Dogger aquifer to the Albian fm. through an abandoned well simulated as a 1D porous medium (formation rock-cement interface) with local grid refinement in the Dogger aquifer (top view).

Fig. $4 \mathrm{CO}_{2}$ phase states for Dogger fm. and Albian fm. based on data from Brosse et al. (2007); André et al. (2007); Vernoux et al. (1997)

Fig. 5 A) Concentrations of chemical species in the Dogger and Albian formation groundwaters B) Mineralogical assemblages of the Albian and Dogger formations

Fig. 6 Relative permeability models for Albian (A) and Dogger (B) formations. Capillary pressure models for Albian (C) and Dogger (D) formations 
Fig. 7 Schematic diagram showing a typical plume of injected fluid of thickness $h(r, t)$ (Nordbotten and Celia 2006); $h(r, t)$ : thickness of the $\mathrm{CO}_{2}$ invading front $(\mathrm{m})$; $\mathrm{i}(\mathrm{r}, \mathrm{t})$ : thickness of $\mathrm{CO}_{2}$ drying front (m); t: time (yrs); r: radial distance from injection well (m); $\mathrm{H}$ : thickness of the formation (m); Qwell: $\mathrm{CO}_{2}$ injection flow $\left(\mathrm{m}^{3} \cdot \mathrm{s}^{-1}\right)$

Fig. 8 Gas phase saturation after 5 days of injection $(0.3 \mathrm{Mt} / \mathrm{yr}) \mathrm{A})$ in the injection well area (Dogger fm.) B) impacted aquifer (Albian fm.)

Fig. 9 Aqueous concentrations ( $\mathrm{Ca}, \mathrm{Fe}$ in $\mathbf{m o l} / \mathbf{k g w}$ ) and $\mathbf{p H}$ in the Albian formation after 5 years

Fig. 10 Evolution of mineral phases during $\mathrm{CO}_{2}$ ingress in the Albian formation (at the top of the leaking well) during $\mathrm{CO}_{2}$ leakage

Fig. 11 A) $\mathrm{CO}_{2}$ saturation and pressure in the Dogger aquifer after 5 years of injection comparison between numerical and analytical results; $\mathrm{B}$ ) $\mathrm{CO}_{2}$ saturation and pressure in the Dogger aquifer below the porous column and $\mathrm{CO}_{2}$ flow in the porous column - comparison between numerical and analytical results

Fig. 12 Sensitivity analysis results: impact on $\mathrm{CO}_{2}$ leakage rate $(\mathrm{kg} / \mathrm{s})$ and $\mathrm{CO}_{2}$ extension bubble extension (m)

\section{List of tables:}

Table 1 Hydro-geochemistry of the three domains: (i) Dogger, (ii) porous column and (iii) Albian.

\begin{tabular}{cccc}
\hline & Dogger aquifer & Porous column & Albian aquifer \\
Porosity & 0.12 & 0.15 & 0.2 \\
Permeability $\left(\mathbf{m}^{2}\right)$ & $6.6710^{-13}$ & $10^{-11}$ & $10^{-12}$ \\
\hline
\end{tabular}




\begin{tabular}{cccc}
\hline $\mathbf{p C O}_{2}$ (bar) & 0.183 & 0.0141 & 0.0141 \\
$\mathbf{p H}$ & 6.7 & 7.36 & 7.36 \\
Salinity $\left(\mathbf{g . k g w} \mathbf{-}^{\mathbf{1}}\right)$ & 5 & 0.5 & 0.5 \\
\hline
\end{tabular}

Table 2 Chemical compositions of the (i) Dogger, (ii) 1D porous column and (iii) Albian formations

\begin{tabular}{cccc}
\hline $\begin{array}{c}\text { Chemical elements } \\
(\mathbf{m o l} / \mathbf{k g w})\end{array}$ & Dogger & Porous column & Albian \\
{$[\mathrm{Ca}]$} & $2.34710^{-3}$ & $1.34610^{-3}$ & $1.34610^{-3}$ \\
{$[\mathrm{Na}]$} & $7.74710^{-2}$ & $8.6510^{-5}$ & $8.6510^{-5}$ \\
{$[\mathrm{Fe}]$} & $1.79310^{-5}$ & $1.28810^{-5}$ & $1.28810^{-5}$ \\
{$\left[\mathrm{CO}_{2 \mathrm{aq}}\right]$} & $7.44710^{-3}$ & $3.52410^{-3}$ & $3.52410^{-3}$ \\
{$[\mathrm{Cl}]$} & $7.04510^{-2}$ & $8.5810^{-5}$ & $8.5810^{-5}$ \\
{$[\mathrm{Mg}]$} & & $8.08610^{-4}$ & $8.08610^{-4}$ \\
{$[\mathrm{~K}]$} & & $1.27810^{-5}$ & $1.27810^{-5}$ \\
{$\left[\mathrm{SiO}_{2 \mathrm{aq}}\right]$} & & $2.22410^{-4}$ & $2.22410^{-4}$ \\
{$[\mathrm{Al}]$} & & $3.58010^{-9}$ & $3.58010^{-9}$ \\
{$\left[\mathrm{SO}_{4}{ }^{2-}\right]$} & & $5.81510^{-4}$ & $5.81510^{-4}$ \\
\hline
\end{tabular}

Table 3 Mineralogical assemblage of the (i) Dogger, (ii) porous column and (iii) Albian formations

Volume fraction of mineral phases

Dogger aquifer Albian aquifer

Calcite

$100 \%$

$19.2 \%$

$\mathrm{CaCO}_{3}$

Quartz

$49 \%$

$\mathrm{SiO}_{2}$

Kaolinite

$15.23 \%$

$\mathrm{Al}_{2} \mathrm{Si}_{2} \mathrm{O}_{5}(\mathrm{OH})_{4}$

Glauconite

(K1.5Mg.5Fe3Al.5)(Al.5Si7.5)O20(OH) ${ }_{4}$

Siderite

$2.18 \%$

$\mathrm{FeCO}_{3}$ 


\begin{tabular}{cc}
\hline Pyrite & $0.5 \%$ \\
$\mathrm{FeS}_{2}$ & \\
\hline
\end{tabular}

Table 4 Specific reactive surface area considered in the model

\section{Reactive surface area $\quad$ Reference}

$\begin{array}{ccc}\text { Pyrite } & 0,147 \mathrm{~m}^{2} / \mathrm{g}=1470 \mathrm{~cm}^{2} / \mathrm{g} & \text { Gleisner et al. (2006) } \\ \text { Glauconite } & 4,4 \mathrm{~m}^{2} / \mathrm{dm} 3=4400 \mathrm{~m}^{2} / \mathrm{m} 3 & \text { Knauss and Wolery (1989) } \\ \text { Kaolinite } & 0,176^{*} 10^{2} \mathrm{~m}^{2} / \mathrm{dm} 3=17600 & \text { Nagy (1995) } \\ \mathrm{m}^{2} / \mathrm{m} 3 & \\ \text { Quartz } & 7,128 \mathrm{~m}^{2} / \mathrm{dm} 3=7128 & \text { Tester et al. (1994) }\end{array}$

Table 5 Kinetic properties for minerals considered in the model (Palandri and Kharaka 2004; B. Elderling 1994)

\begin{tabular}{|c|c|c|c|c|c|c|c|c|}
\hline & \multicolumn{3}{|c|}{ Acid mechanism } & \multicolumn{2}{|c|}{$\begin{array}{c}\text { Neutral } \\
\text { mechanism }\end{array}$} & \multicolumn{3}{|c|}{ Base mechanism } \\
\hline & ${ }^{1} \log k$ & ${ }^{2} E$ & ${ }^{3} \mathrm{n}\left(\mathrm{H}^{+}\right)$ & ${ }^{1} \log k$ & ${ }^{2} E$ & ${ }^{1} \log k$ & ${ }^{2} E$ & ${ }^{3} \mathrm{n}\left(\mathrm{H}^{+}\right)$ \\
\hline Pyrite & & & & $-9.22^{*}$ & 56.9 & & & \\
\hline Glauconite & -4.8 & 85 & 0.7 & -9.1 & 85 & - & - & - \\
\hline Kaolinite & -11.31 & 65.9 & 0.777 & -13.18 & 22.2 & -17.05 & 17.9 & -0.472 \\
\hline Quartz & & & & -13.99 & 87.7 & & & \\
\hline \multicolumn{9}{|c|}{${ }^{1}$. Rate constant $\mathrm{k}$ computed from $\mathrm{A}$ and $\mathrm{E}, 25^{\circ} \mathrm{C}, \mathrm{pH}=0, \mathrm{~mol}_{\mathrm{m}}-^{2} . \mathrm{s}^{-1}$} \\
\hline \multicolumn{9}{|c|}{${ }^{2}$. Arrhenius activation energy E, Kj.mol- ${ }^{1}$} \\
\hline \multicolumn{9}{|c|}{ 3. Reaction order $\mathrm{n}$ with respect to $\mathrm{H}^{+}$} \\
\hline \multicolumn{9}{|c|}{ * According to B. Elderling and al., 1994} \\
\hline
\end{tabular}


Table 6 Relative permeability and capillary pressure model of the (i) Dogger, (ii) Albian formations

\begin{tabular}{|c|c|c|}
\hline & Albian aquifer & Dogger aquifer \\
\hline $\begin{array}{l}\text { Relative permeability } \\
\text { (Van Genuchten) }\end{array}$ & $\begin{array}{l}\text { From Sleipner field } \\
\text { parameters (Utsira } \\
\text { sandstones) }\end{array}$ & $\begin{array}{c}\text { From Lavoux limestones } \\
\text { parameters }\end{array}$ \\
\hline$\lambda=1-1 / n$ & 0.63 & 0.6 \\
\hline $\begin{array}{l}\text { Residual liquid phase } \\
\text { saturation (SIr) }\end{array}$ & 0.05 & 0.2 \\
\hline $\begin{array}{l}\text { Liquid phase saturation } \\
\qquad(\mathrm{Sls})\end{array}$ & 1.0 & 1.0 \\
\hline $\begin{array}{l}\text { Irreductible gas saturation } \\
\qquad(\mathrm{Sgr})\end{array}$ & 0.2 & 0.05 \\
\hline $\begin{array}{c}\text { Capillary pressure (Van } \\
\text { Genuchten) }\end{array}$ & $\begin{array}{l}\text { From Sleipner field } \\
\text { parameters (Utsira } \\
\text { sandstones) }\end{array}$ & $\begin{array}{c}\text { From Lavoux limestones } \\
\text { parameters }\end{array}$ \\
\hline$\lambda=1-1 / n$ & 0.63 & 0.6 \\
\hline $\begin{array}{l}\text { Residual liquid phase } \\
\text { saturation (SIr) }\end{array}$ & 0.05 & 0.199 \\
\hline $\mathrm{Po}(\mathrm{Pa})$ & 1400 & 54000 \\
\hline $\begin{array}{l}\text { Initial liquid phase } \\
\text { saturation (Sls) }\end{array}$ & 1.0 & 1.0 \\
\hline
\end{tabular}


Table $7 \mathrm{CO}_{2}$ plume extension and pressure models parameters 


\begin{tabular}{|c|c|c|c|}
\hline & Model parameters & $\begin{array}{l}\text { Steady case value or } \\
\text { reference source }\end{array}$ & Variability or dependence \\
\hline k & Dogger permeability $\left(\mathrm{m}^{2}\right)$ & $6.67 .10^{-13}$ & $\begin{array}{l}1.10^{-14} ; 2.610^{-14} ; 5.210^{-14} ; 7.710^{-14} \text {; } \\
1.10^{-13} ; 2.610^{-13} ; 5.110^{-13} ; 6.910^{-13} ; \\
1.10^{-12}\end{array}$ \\
\hline e & Dogger porosity (-) & 0.12 & $\begin{array}{l}0.05 ; 0.07 ; 0.1 ; 0.12 ; 0.15 ; 0.17 \\
0.2 ; 0.22 ; 0.25 ; 0.27 ; 0.3\end{array}$ \\
\hline SIr & $\begin{array}{l}\text { Dogger Residual liquid } \\
\text { phase saturation }(-)\end{array}$ & 0.2 & $\begin{array}{l}0.1 ; 0.16 ; 0.2 ; 0.26 ; 0.32 ; 0.378 \\
0.43 ; 0.49 ; 0.54 ; 0.6 \text { (Bachu and } \\
\text { Bennion 2007) }\end{array}$ \\
\hline $\mathrm{k}_{\mathrm{r}}$ & $\begin{array}{l}\text { Dogger } \mathrm{CO}_{2} \text { end point } \\
\text { relative permeability (-) }\end{array}$ & $\begin{array}{l}\text { Calculated according } \\
\text { to Van Genuchten } \\
\text { model with } \lambda=1-1 / n= \\
0.6\end{array}$ & $0.01<\lambda<0.18$ \\
\hline$\rho_{\mathrm{c}} / \mu_{\mathrm{c}}$ & $\begin{array}{l}\mathrm{CO}_{2} \text { density and viscosity } \\
\left(\mathrm{kg} / \mathrm{m}^{3}, \mathrm{mPa} . \mathrm{s}\right)\end{array}$ & Duan et al. (1992) & Temperature, pressure \\
\hline$\rho_{\mathrm{w}}$ & Brine density $\left(\mathrm{kg} \cdot \mathrm{m}^{-3}\right)$ & Phillips et al. (1981) & Temperature, pressure, salinity \\
\hline$\mu_{\mathrm{w}}$ & Brine viscosity (mPa.s) & $\begin{array}{l}\text { Batzle and Wang } \\
(1992)\end{array}$ & Temperature, salinity \\
\hline$\beta_{1} / \beta_{2}$ & $\mathrm{CO}_{2} /$ Brine solubilities (\%) & $\begin{array}{l}\text { Spycher and Pruess } \\
\text { (2005) }\end{array}$ & Temperature and pressure \\
\hline $\mathrm{C}_{\mathrm{r}}$ & Rock compressibility $\left(\mathrm{Pa}^{-1}\right)$ & $4.5 .10^{-10}$ & No variability \\
\hline $\mathrm{C}_{\mathrm{w}}$ & Brine compressibility $\left(\mathrm{Pa}^{-1}\right)$ & $\begin{array}{l}\text { Meehan (1980) } \\
\text { Numbere et al. (1977) }\end{array}$ & Temperature, pressure, salinity \\
\hline $\mathrm{H}$ & Dogger thickness $(\mathrm{m})$ & 30 & No variability \\
\hline $\mathrm{Q}_{w}$ & $\begin{array}{l}\text { Volumetric injection flow } \\
\left(\mathrm{m}^{3} \mathrm{~s}^{-1}\right)\end{array}$ & $2.41 .10^{-2}\left(\approx 12.7{\mathrm{~kg} . \mathrm{s}^{-1}}^{-1}\right)$ & No variability \\
\hline Dogger & Temperature $\left({ }^{\circ} \mathrm{C}\right)$ & 65.6 & No variability \\
\hline Dogger & Pressure (MPa) & 14.64 & No variability \\
\hline Dogger & Salinity $\left(g \cdot \mathrm{kgw}^{-1}\right)$ & 5 & No variability \\
\hline $\begin{array}{l}\text { Tempe } \\
\text { column }\end{array}$ & rature gradient in the porous & $3.97^{\circ} \mathrm{K} / 100 \mathrm{~m}$ & No variability \\
\hline $\begin{array}{l}\text { Pressu } \\
\text { column }\end{array}$ & re gradient in the porous & $0.1 \mathrm{bar} / \mathrm{m}$ & No variability \\
\hline $\mathrm{k}_{\mathrm{col}}$ & $\begin{array}{l}\text { Porous column } \\
\text { permeability }\left(\mathrm{m}^{2}\right)\end{array}$ & $10^{-11}$ & $\begin{array}{l}1.10^{-13} ; 5.110^{-13} ; 1.10^{-12} ; 5.110^{-12} \\
1.10^{-11} ; 5.110^{-11} ; 1.10^{-10}\end{array}$ \\
\hline
\end{tabular}




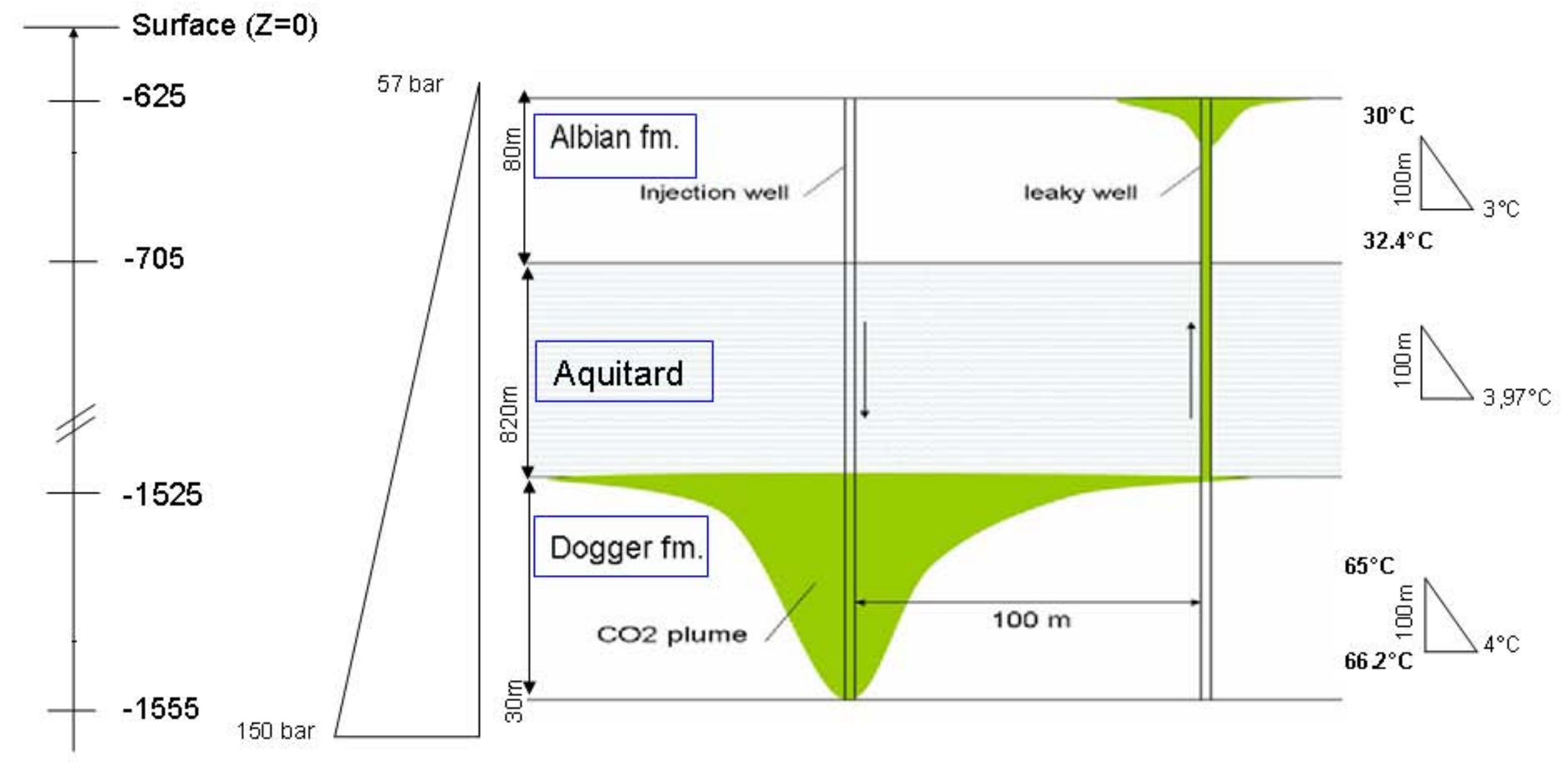

$Z$ (m) without reference to sea level

Hydrostatic pressure 


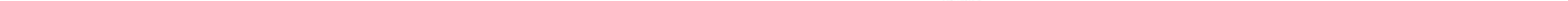




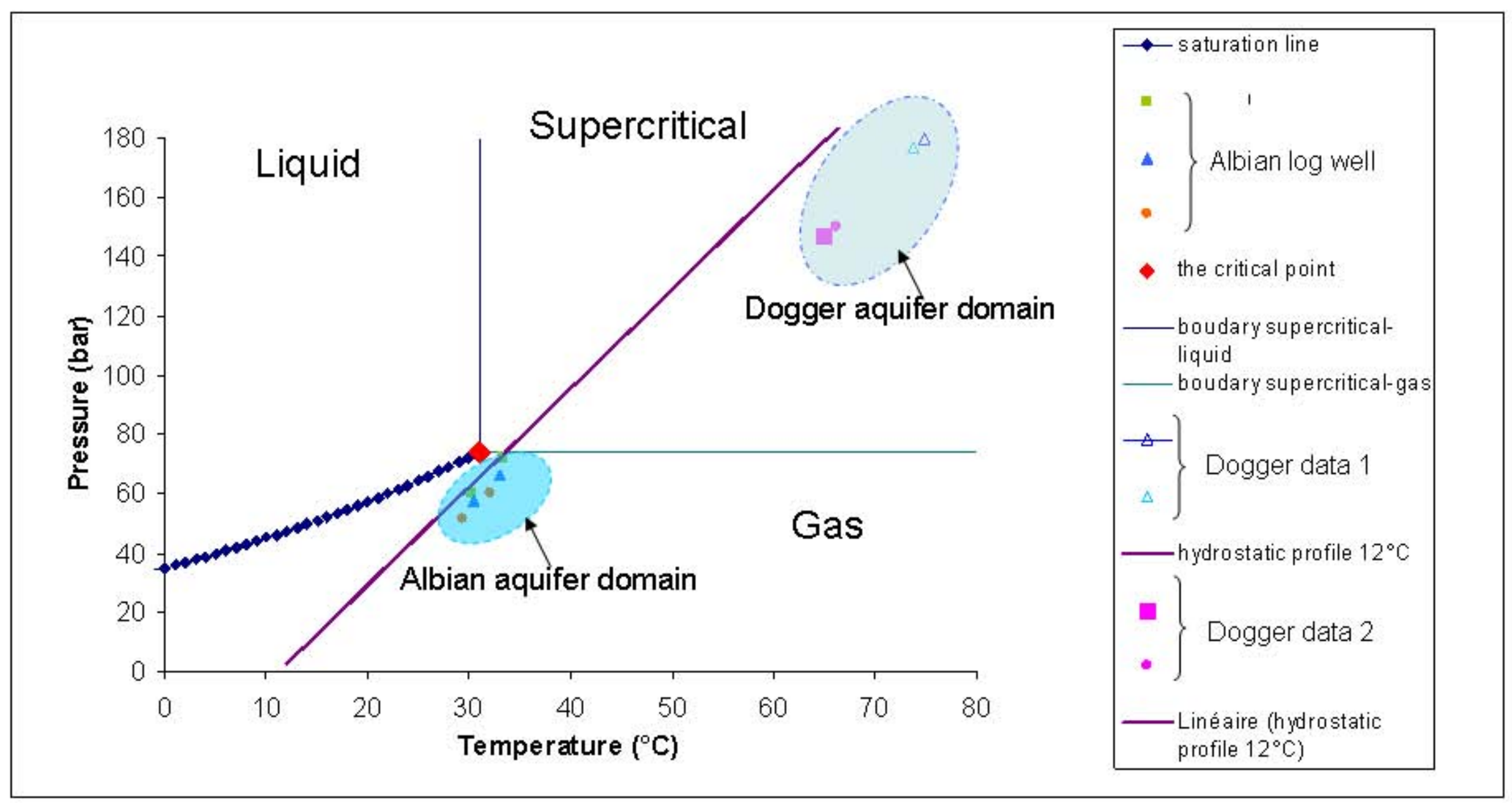




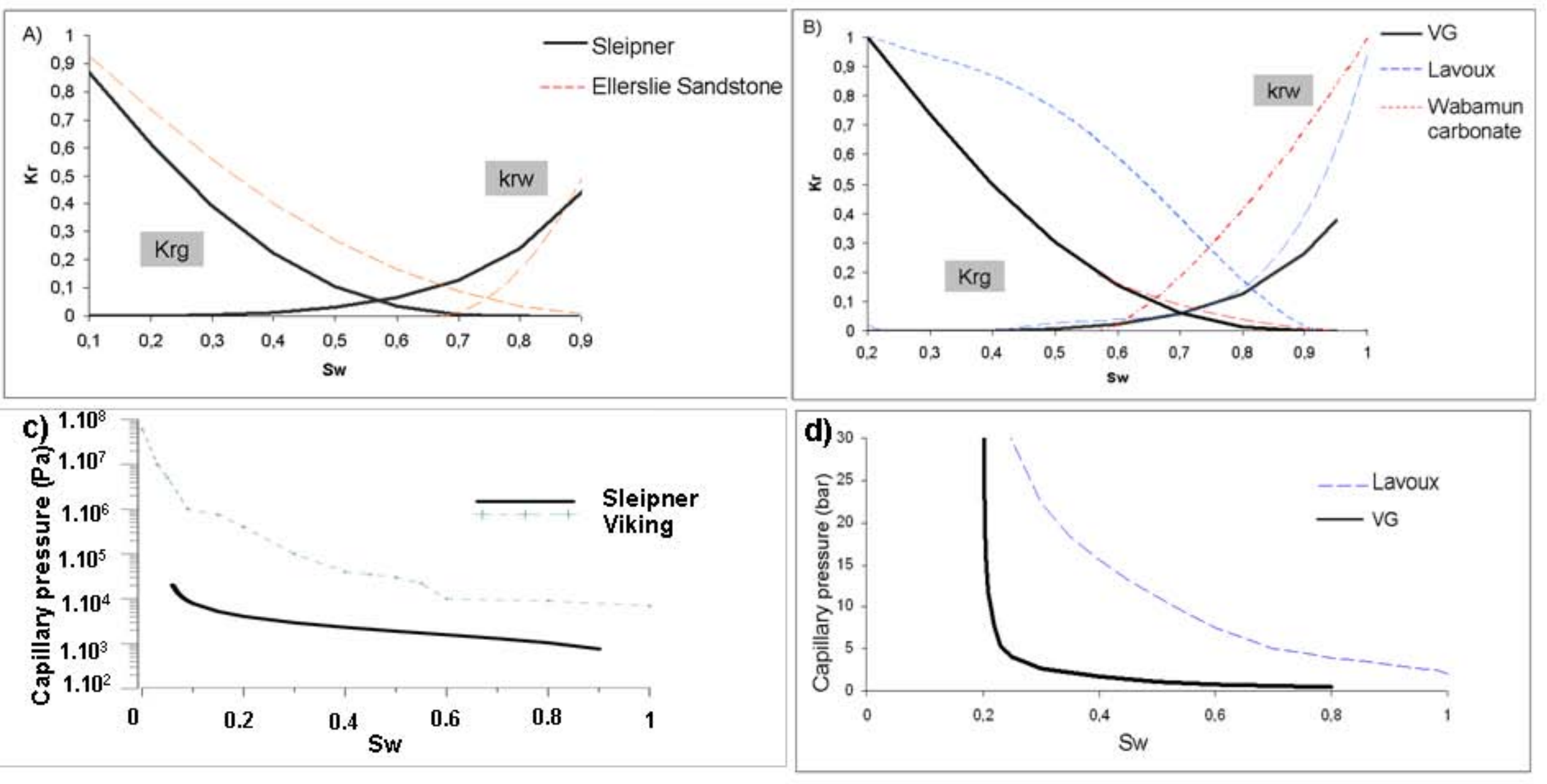




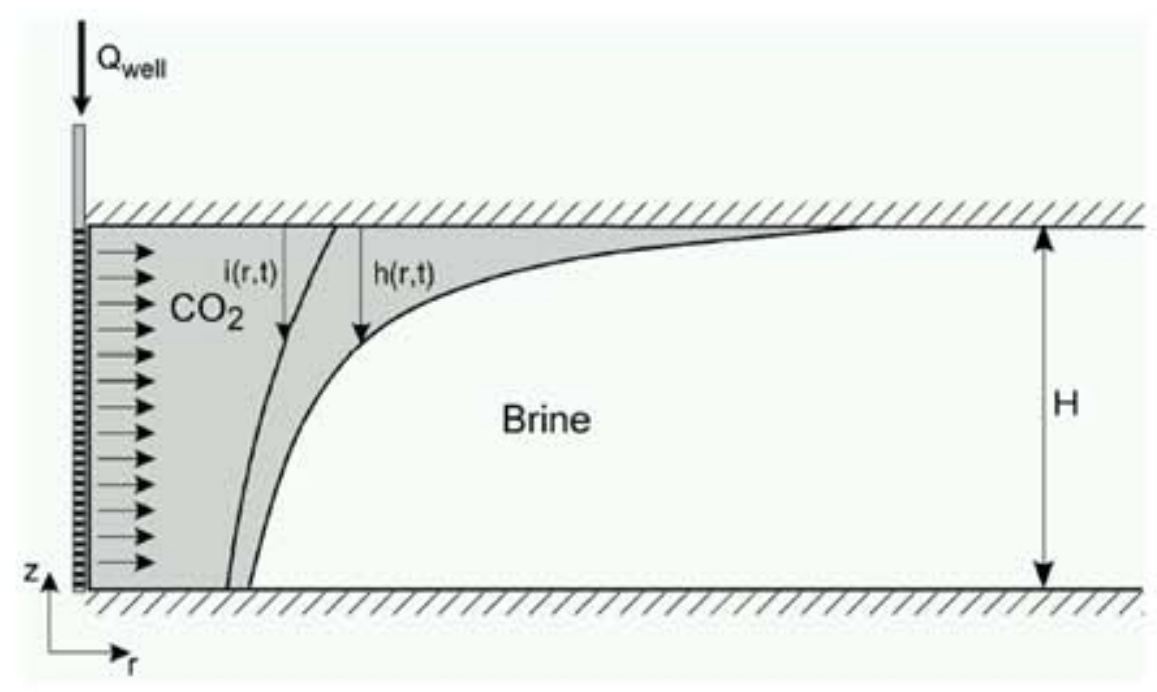



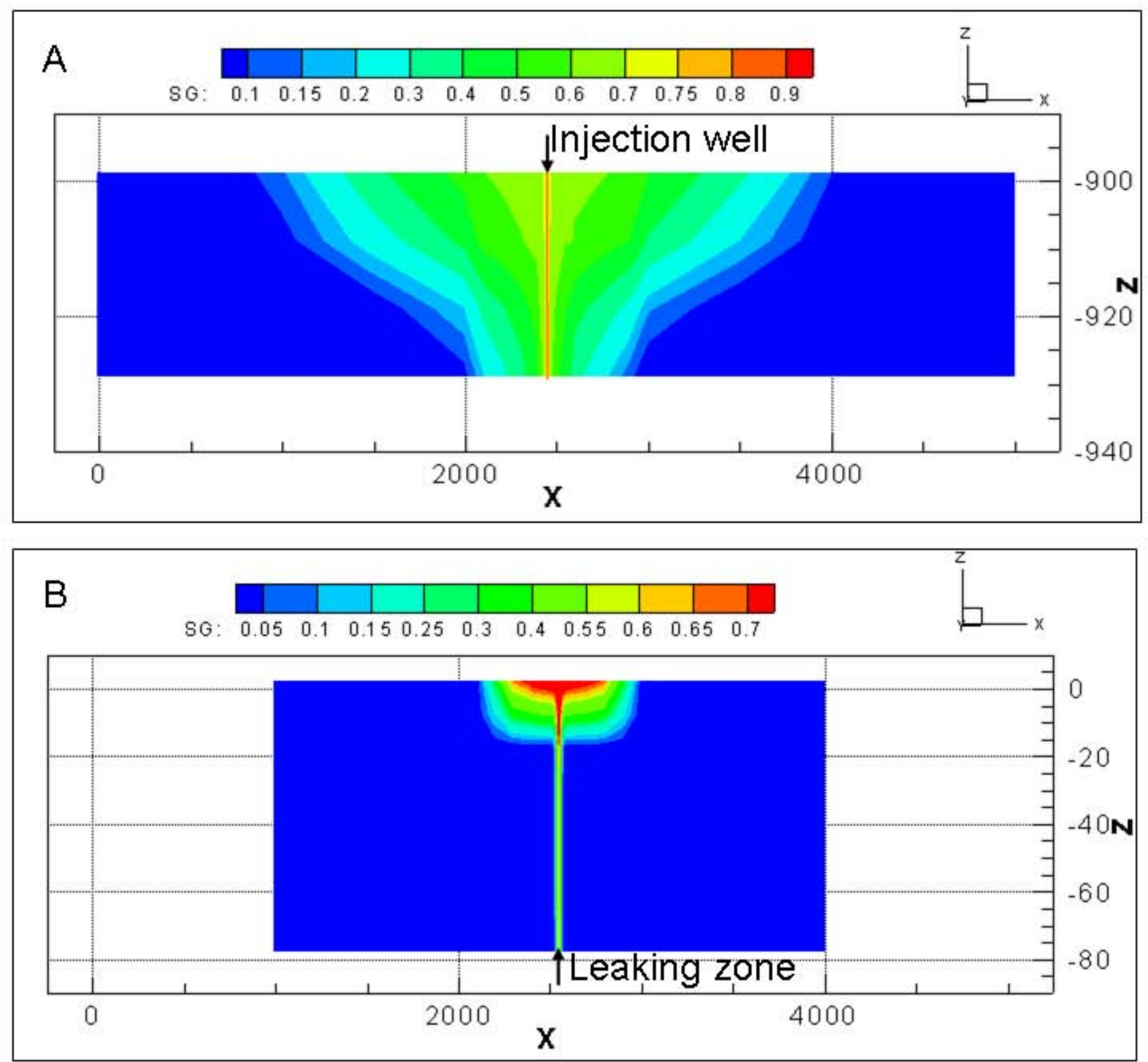


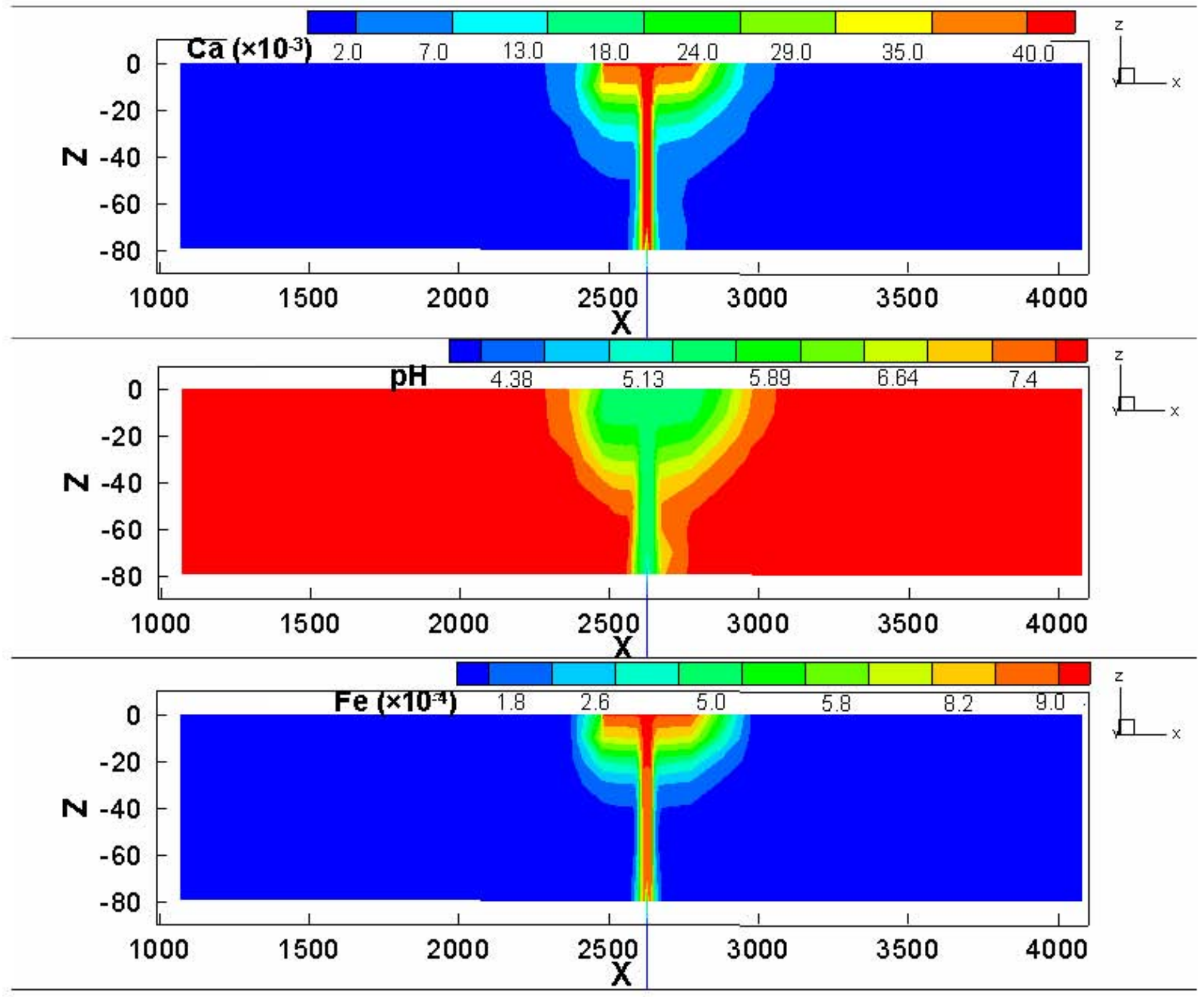




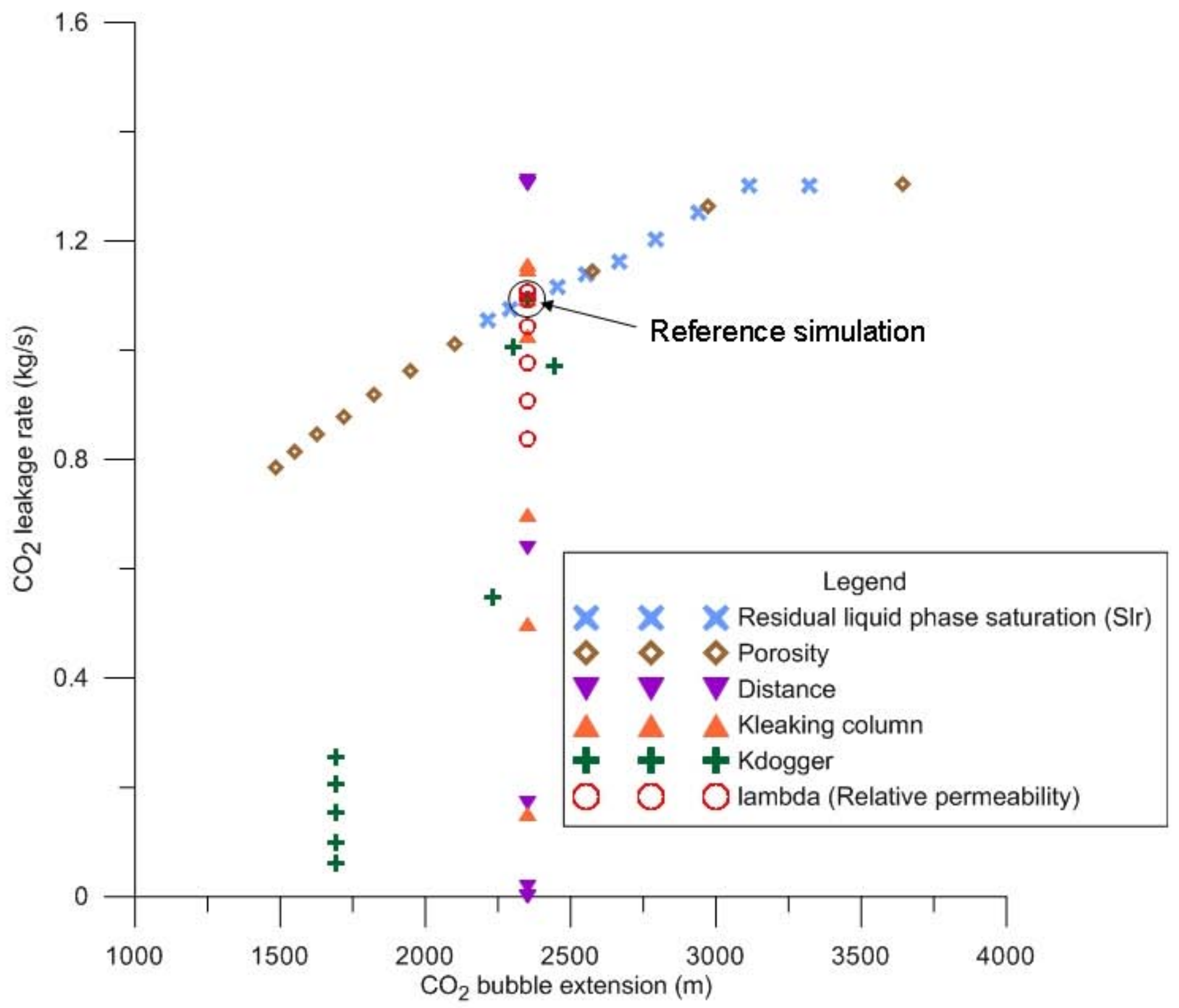

